\title{
Kaya Tutma Hendek Performansının 3-Boyutlu Kaya Düşme Analizleriyle Değerlendirilmesi: Akköy (Ürgüp) Örneği
}

\author{
Evaluation of the Performance of a Rockfall Ditch by 3-Dimensional Rockfall Analyses: \\ Akköy (Ürgüp) Case
}

\author{
Mutluhan AKIN ${ }^{1} \mathbb{D}$, İsmail DİNÇER ${ }^{1} \mathbb{D}$, Ahmet ORHAN ${ }^{1} \mathbb{D}$, \\ Ali Özgün OK $^{2} \mathbb{D}$, Müge K. AKIN ${ }^{3} \mathbb{D}$, Tamer TOPAL ${ }^{4} \mathbb{D}$
}

${ }^{1}$ Nevşehir Hacı Bektaş Veli Üniversitesi, Jeoloji Mühendisliği Bölümü, Nevşehir

${ }^{2}$ Hacettepe Üniversitesi, Geomatik Mühendisliği Bölümü, Ankara

${ }^{3}$ Abdullah Gül Üniversitesi, Inş̧aat Mühendisliği Bölümü, Kayseri

${ }^{4}$ Orta Doğu Teknik Üniversitesi, Jeoloji Mühendisliği Bölümü, Ankara

Geliş (Received): 08 Mart (March) 2019 / Düzeltme (Revised): 09 Nisan (April) 2019 / Kabul (Accepted): 20 Nisan (April) 2019

\section{ÖZ}

Nüfus yoğunluğunun fazla olmadığı kaya düşme tehlikesi altındaki yerleşim yerlerinde kaya düşmelerinden korunmak amaciyla kaya tutma hendekleri veya alanları inşa edilebilmektedir. Ancak, bu tür koruma yapılarının tasarımında çoğu zaman sahaya özgü gerekli mühendislik incelemeleri ve analizleri yeterince gerçekleştirilmemektedir. Bu nedenle, kaya tutma hendekleri zaman zaman kaya düşmelerinden korunmada yeterli olamamaktadır. $\mathrm{Bu}$ çalışma kapsamında, turistik işletmelerin de bulunduğu Akköy (Ürgüp) yerleşiminde düşen kaya bloklarının yaşam alanlarına ulaşmasını engellemek amacıyla üst kotlarda 2012 yılında inşa edilen $2 \mathrm{~m}$ derinliğindeki ve $1 \mathrm{~km}$ uzunluğundaki kaya tutma hendeğinin performansı 3-boyutlu kaya düşme analizleri ile değerlendirilmiştir. Yapılan kaya düşme risk sınıflamasına göre yerleşim orta derecede kaya düşme riski altındadır. 3-boyutlu kaya düşme analizlerinde kullanılan sayısal yüzey modeli insansız hava aracı ile alınan fotogrametrik görüntülerden elde edilen nokta bulutu verisi ile oluşturulmuştur. Arazi gözlemlerinde daha önceden düşen ignimbirit bloklarının boyutlarının 2 m’ye ulaşabildiği belirlenmiş̧ir. Öte yandan, kaynak bölgesindeki yüksek süreksizlik devamlılı̆̆ı, düşebilecek blokların boyutlarının da büyük olabileceğini işaret etmektedir. RocPro3D yazılımında gerçekleştirilen 3-boyutlu kaya düşme analizleri sonucunda, genel olarak düşen blokların kaynak zon ile yerleşim yeri arasında kazılan hendek tarafından tutulduğu ancak bazı bölümlerde bu blokların kaya tutma hendeğini aşarak yuvarlanmaya devam edebileceği ortaya konmuştur. Buna göre, Akköy yerleşimi kısmen de olsa halen kaya düşme tehlikesi altındadır. Kaya tutma hendeğinin zaman içerisinde periyodik olarak temizliği yapılmadığ takdirde hendeğin kapasitesinin azalması ile birlikte tehlikenin boyutu daha da artacaktır.

Anahtar Kelimeler: Kaya Düşmesi, Hendek, 3-Boyut, Performans, Ürgüp

\section{ABSTRACT}

Rockfall ditches or areas can be constructed in order to protect against rockfalls in settlements that are in danger of rockfalls when the population density is not high. Nevertheless, in the design of such protection structures, essential site-specific engineering studies and analyzes are often not carried out appropriately. Therefore, rockfall 
Akın, Dinçer, Orhan, Ok, Akın, Topal

ditches are occasionally not capable of preventing rockfalls. Within the scope of this study, the performance of a 2 $m$-deep and $1 \mathrm{~km}$-long rockfall ditch excavated at the upper elevation of touristic Akköy (Ürgüp) settlement in 2012 in order to prevent the entrance of falling rocks to the residential area was evaluated on the basis of 3-dimensional rockfall analyses. According to the rockfall risk classification, the settlement is under moderate rockfall risk. The digital surface model used in 3-dimensional rockfall analyses was generated by point cloud data obtained from photogrammetric images taken by unmanned aerial vehicle. During field observations, it was determined that the dimension of the previously fallen ignimbrite blocks could reach up to $2 \mathrm{~m}$. On the other hand, the high persistency of discontinuities in the source zone indicates that the dimensions of the potential rockfall blocks may be large. As a result of the 3-dimensional rockfall analyses carried out in RocPro3D software, it was defined that the falling blocks are generally caught by the ditch excavated between the source zone and the settlement, but in some sections of the ditch those blocks may continue to roll over the rockfall ditch. Eventually, Akköy settlement is still partially under the danger of rockfalls. If the rockfall ditch is not periodically cleaned in the course of time, the extent of danger will enlarge with the decrease in the capacity of the trench.

Keywords: Rockfall, ditch, 3-dimension, performance, Ürgüp

\section{GİRIŞ}

Kaya kütle duraysızlıklarından biri olan kaya düşmesi, yamaç veya şevlerde süreksizlik yüzeyleri boyunca ayrilan kaya bloklarının yerçekiminin etkisiyle yamaç/şev eğimi yönündeki oldukça hızlı ve ani hareketi olarak tanımlanabilir (Varnes, 1978). Süreksizlik yüzeylerindeki suların donma-çözülme etkisi ile oluşturduğu basınçlar, ağaç köklerinin büyümesi, ayrışma ve deprem dalgaları gibi çeşitli faktörlerin etkisi altında kaynak zondan kopan kaya blokları, dik yamaçlardan aşağı doğru serbest düşerek, eğimin azalmasına bağlı olarak yuvarlanarak, kayarak ve/veya sıçrayarak hareket ederler (Wyllie, 2015). Kaya düşmeleri, kaynak alan ve tetikleyici unsurlar açısından değerlendirildiğinde kestirilmesi güç bir kütle duraysızlık türüdür. Yamaç yüzeyinde uzun süre duraylılı̆̆ını koruyan bloklar, aniden kütleden ayrılarak düşebilmekte, can ve mal kaybına neden olabilmektedir.

Bilindiği üzere ülkemiz jeolojik, morfolojik ve iklimsel konumu gereği farklı doğal afetlerin tehdidi altındadır. Ortaya çıkardıkları etki açısından depremler öne çıkan en önemli doğal afet türü olmasına rağmen, kaya kütle duraysızlıkları ve özellikle kaya düşmeleri de ülkemizin maruz kaldığ biridir. Bu bağlamda, can ve mal kaybına neden olan kaya düşme sıklığı açısından değerlendirildiğinde ülkemiz içerisinde Kayseri, Erzurum ve Nevşehir illeri ön plana çıkmaktadır (Gökçe vd., 2008). Kaya düşmesi kaynaklı problemlerin önüne geçilebilmesi için yerleşim yerlerinde ve ulaşım güzergahlarında kaya düşme analizlerinin yapılarak tehlike sınırlarının belirlenmesi oldukça önemlidir (Topal vd., 2007; Tunusluoğlu ve Zorlu, 2009; Topal vd., 2012; Dinçer vd., 2016; Kayabaş1, 2018; Sarro vd., 2018; Fanos ve Pradhan, 2019). Büyük bir bölümü Nevşehir ili sınırları içerisinde yer alan Kapadokya yöresinde kaya düşmelerinin can ve mal kaybına neden olmasının yanı sıra, kültürel ve doğal miras üzerinde de olumsuz etkileri bulunmaktadır. Kapadokya ve çevresinde kaya düşmelerinin yoğunlaştığı alanlar jeolojik birimler açısından değerlendirildiğinde, mevcut duraysızlıklar Neojen yaşlı volkanik birimler içerisinde meydana gelirken, litolojiler üzerindeki farklı erozyon etkilerinin kaya düşmelerini tetikleyen en önemli unsur olduğu belirtilmiştir (Zorlu vd., 2011). Düşük yamaç eğimine sahip alt seviyelerde marn, kiltaşı ve tüf gibi ayrışmaya ve erozyona karşı düşük duraylılığa sahip volkanosedimanter birimler yer alırken, dik 
morfoloji sunan ve kaya düşmeleri için kaynak zonunu oluşturan üst seviyelerde ise bazalt ve iyi kaynaşmış ignimbirit gibi daha duraylı litolojiler gözlenmektedir. Bu tür jeolojik ve morfolojik yapıların gözlendiği alanlarda önemli ölçüde kaya düşmesi tehlikesi yaşanmaktadır.

Kaya düşmelerinin meydana gelmesini ve ulaşım hatlarına veya yerleşim yerlerine zarar vermesini önlemek amacıyla birçok farklı yapısal önlem ve koruma yöntemi bulunmaktadır. Bu yöntemlerin bir kısmı ağaçlandırma, kaya tutma hendekleri ve toprak seddeler gibi doğal veya yarı-doğal çözümleri içerirken, diğer önemli bir bölümü de tamamen endüstriyel malzemelerden üretilen kaya tutma bariyerleri ve duvar türü yapıları kapsamaktadır (Volkwein vd., 2011). Kaya tutma hendekleri, düşen kaya bloklarını tehlike altındaki yerleşim yerlerine veya ulaşım hatlarına ulaşmadan önce enerjilerini düz veya ters eğimli topoğrafik yüzeyler üzerinde veya belirli derinlikteki çukurlar içerisinde sönümleyerek durdurmaya yarayan, çok fazla mühendislik uygulaması gerektirmeyen, ekonomik kaya düşmesi koruma yöntemlerinden bir tanesidir (Şekil 1). Kaya tutma hendeklerinin yapımı ve bakımı kolay, imalatları da maliyetli olmadığından, ulaşım hatları kenarlarında ve küçük yerleşim yerlerinin üst kotlarında kaya düşmelerinden korunmak amaciyla sıklıkla tercih edilmektedirler.

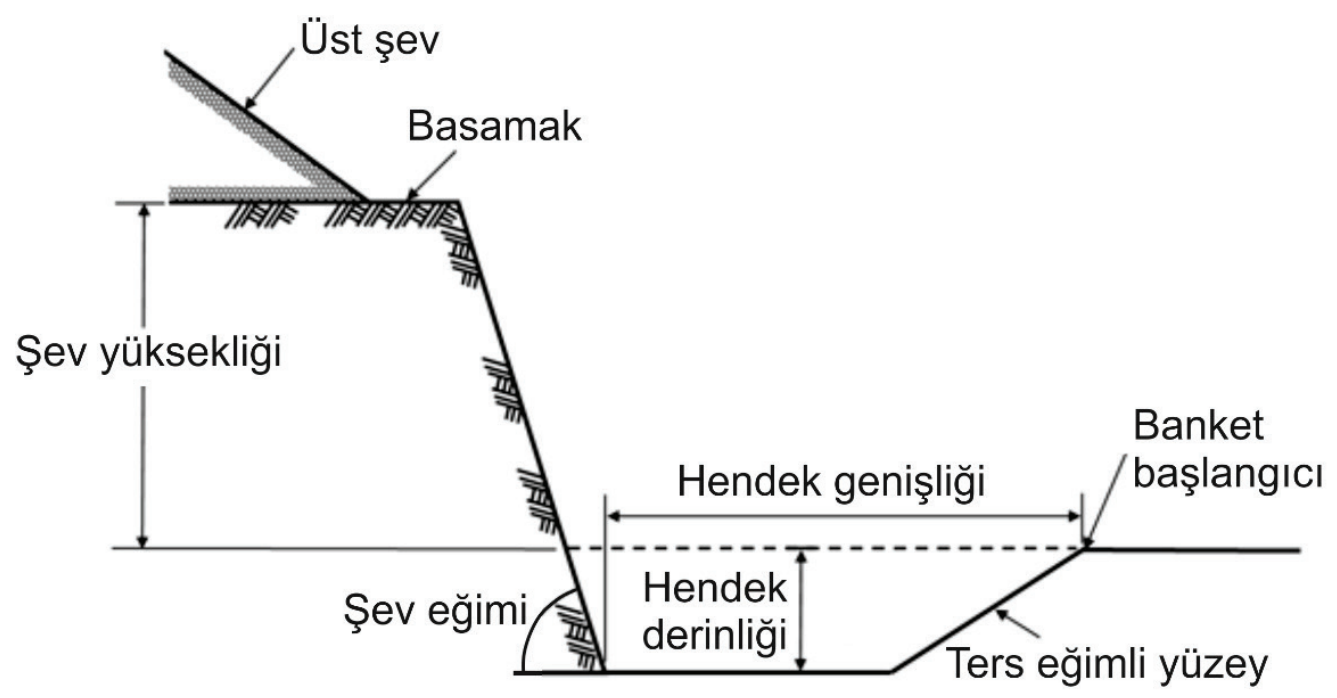

Şekil 1. Bir kaya tutma hendeğinin genel kesit görünümü (Turner ve Schuster, 2012).

Figure 1. A general cross-sectional view of rockfall ditch (Turner and Schuster, 2012). 
Akın, Dinçer, Orhan, Ok, Akın, Topal

Bir kaya tutma hendeğinin düşen kaya bloklarını durdurabilmesi için doğru geometride ve lokasyonda projelendirilmesi oldukça önemlidir. Bu tasarımda göz önüne alınması gereken başlıca nitelikler arasında hendeğin yeri, genişliği, derinliği, şekli ve taban yapısı yer almaktadır. Bu nedenle hendek bileşenlerin tasarlanmasinda incelenen sahaya ait kaya düşmesi hatlarına ait özelliklerin ve düşen blokların dinamik özelliklerinin bilinmesi gerekmektedir. $\mathrm{Bu}$ amaçla, kaya tutma hendeklerinin projelendirilmesinde başlıca iki yöntem izlenebilir. Birinci yöntemde hendek tasarımı Ritchie Hendek Ölçütü (Ritchie, 1963; FHWA, 1989) veya Kaya Düşmesi Tutma Alanları Tasarım Rehberi (Pierson vd., 2001) gibi önceden hazırlanmış grafikler veya yol gösterici şartnameler doğrultusunda yapılabilmektedir. İkinci ve daha gerçekçi olan yöntemde ise 2 veya 3-boyutlu kaya düşme analizleri gerçekleştirildikten sonra kaya bloklarının davranış özellikleri ortaya konmakta ve belirlenen blok sıçrama yükseklikleri, darbe noktaları vb. gibi parametrelere bağlı olarak kaya tutma hendeklerinin boyutlandırması yapılabilmektedir. Ancak, uygulamalarda çoğu zaman herhangi bir tasarım ölçütü kullanılmadan veya kaya düşme modellemeleri gerçekleştirilmeden kaya tutma hendekleri inşa edilebilmektedir.

$\mathrm{Bu}$ çalışma kapsamında, kaya düşmelerinin yoğun olarak gözlendiği bir yerleşim yeri olan Akköy'de (Ürgüp-Nevşehir) 2012 yılında inşa edilen kaya tutma hendeğinin, kaya düşmelerinin önlenmesinde gösterebileceği performans 3-boyutlu kaya düşme analizleri ile değerlendirilmiştir. İnceleme alanına ait yerbulduru haritası Şekil 2'de sunulmaktadır.

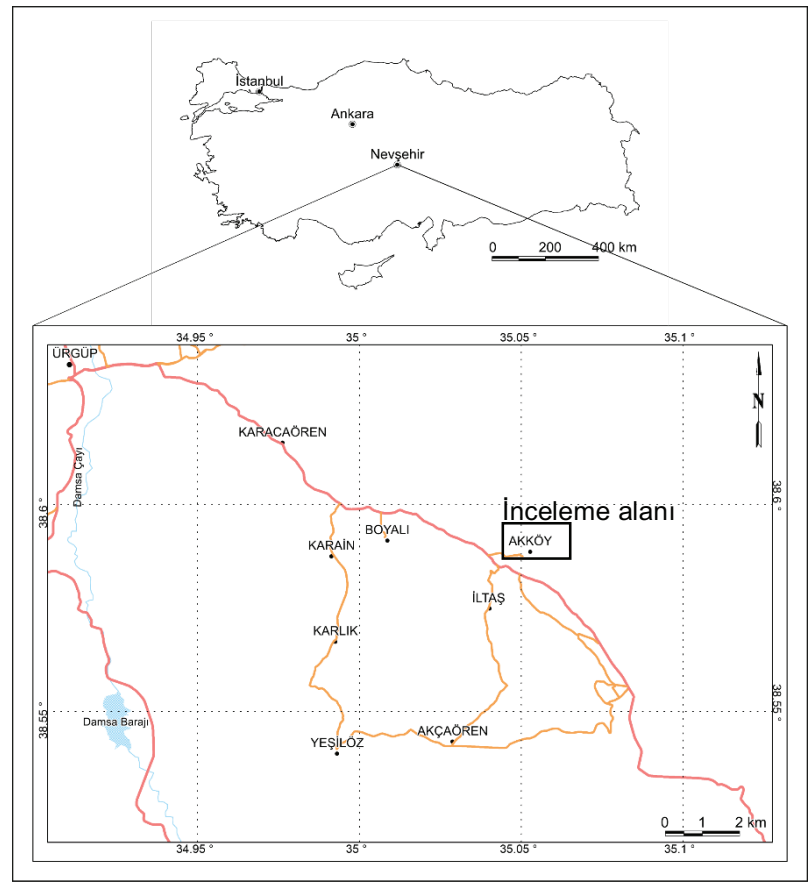

Şekil 2. İnceleme alanı yerbulduru haritası.

Figure 2. Location map of the study area. 
INCELEME ALANININ TANITIMI VE JEOLOJISII

Akköy yerleşimi Ürgüp'ün yaklaş1k 15 km güneydoğusunda yer almaktadır. Yerleşim sarp bir topoğrafyanın yamaçlarında kurulmuştur. Köy statüsünde bulunmasına rağmen Akköy'de halen faaliyet gösteren turistik tesisler mevcuttur. Yerli ve yabanc1 turistler doğa güzellikleri ve sakinlik açısından bu yerleşim yerinde konaklamaktadır.
Bölgede 2010'lu yıllardan önce meydana gelen kaya düşmeleri nedeniyle yerleşim halkı ve turistler can ve mal kaybı tehlikesiyle karşı karşıya kalmıştır. Bu nedenle, 2012 yılında İl Özel İdaresi ve Afet ve Acil Durum Yönetimi (AFAD) Başkanlığı tarafindan yerleşimin üst kotlarındaki dik kayalıkların topuk kısmında yaklaşık $2 \mathrm{~m}$ derinliğinde ve $1 \mathrm{~km}$ uzunluğunda bir kaya tutma hendeği imal edilmiştir (Şekil 3).

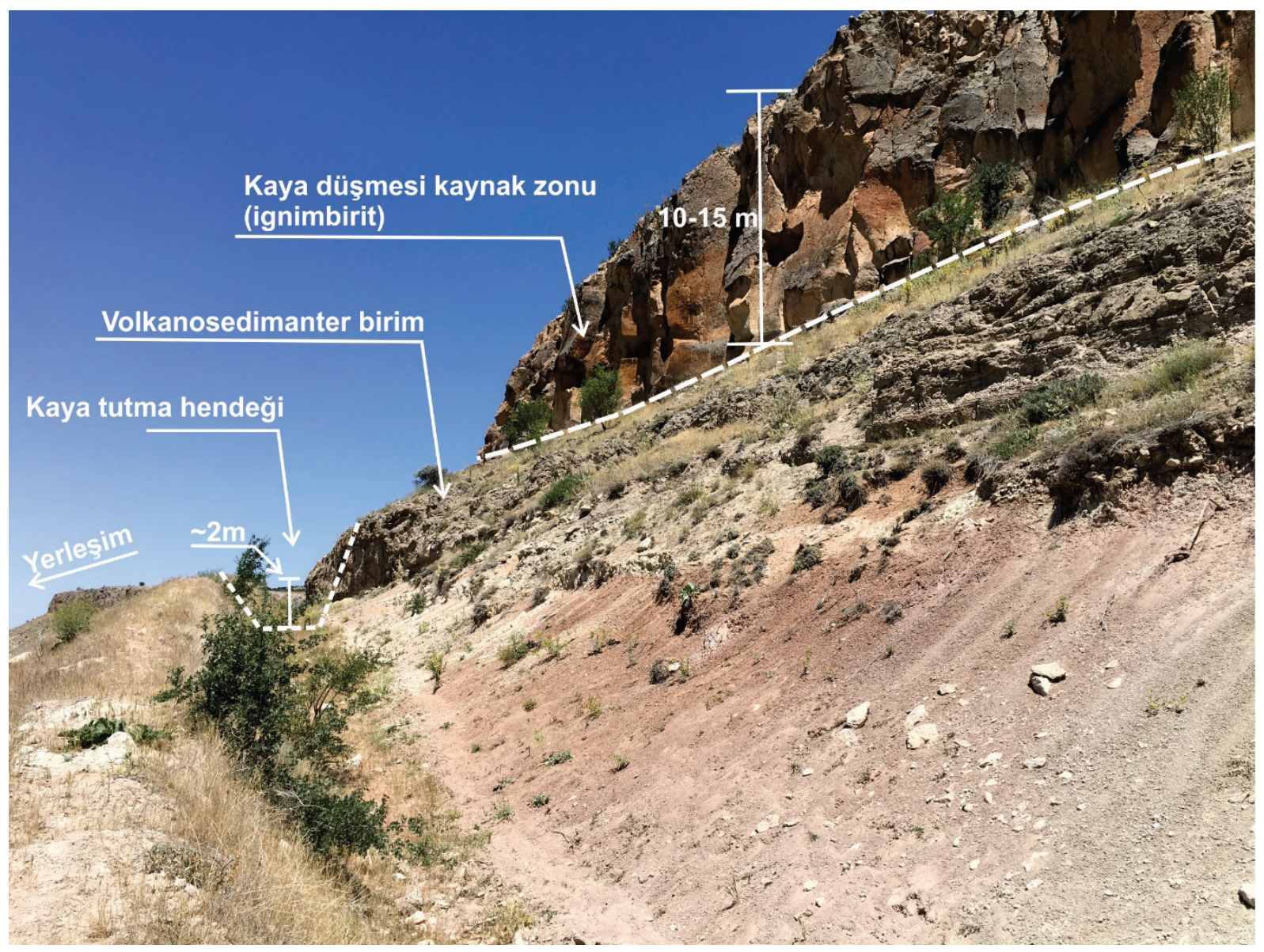

Şekil 3. İnceleme alanındaki kaya tutma hendeğinden ve kaynak zonundan bir görünüm.

Figure 3. A view of rockfall ditch and source zone at the study area. 
Akın, Dinçer, Orhan, Ok, Akın, Topal

Akköy ve yakın çevresine ait jeoloji haritası Şekil 4'te gösterilmiştir. Akköy yerleşiminin bulunduğu bölgede, jeoloji haritasından da görüleceği üzere, Ürgüp Formasyonu'na ait farklı volkanik ve volkanosedimanter kaya birimleri yayılım göstermektedir. İnceleme alanının üst kotlarında Topuzdağı Bazaltı (Tüt1) olarak adlandırılan kısmen mafik bazaltik lav akıntısı yer almaktadır. Birimin alt düzeyleri olivinsiz, ojit ve hiperstence zengin, üst seviyeleri ise olivin bazalt özelliğindedir. Akköy’ün kuzeydoğusunda, Topuzdağı Bazaltı'nın alt seviyelerinde inceleme alanındaki kaya düşmelerinin de kaynak zonunu oluşturan ignimbiritler yer almaktadır. Ürgüp Formasyonu Salur üyesi (Tüs1) genelde kum, kumtaşı ve tüflü çakıltaşından oluşmaktadır. Çakılların hemen hepsi gri - siyah bazalt ve andezit türündedir. Aynı bileșimli piroklastik malzeme de içerir. Ürgüp Formasyonu İncesu üyesi (Tüi) genel olarak inci grisi, pembe renkli, ignimbirit ve dasitik tüften oluşmaktadır. Birimde üç düzey ayırtlanmıştır. Alt düzey ince taneli, homojen, gözeneksiz, kaynaşmamış olup, pomzaca zengindir. Makro biyotit, kuvars ve feldspat içerir. Orta düzey gözenekli ve orta tanelidir. Matriksi alt düzey ile aynıdır. Üst düzey ise masif, ince - orta taneli, boşluksuz, volkanik cam parçaları ve pomza içermektedir. Birimin yaklaşık kalınlığı 60 m’dir (Atabey, 1989).

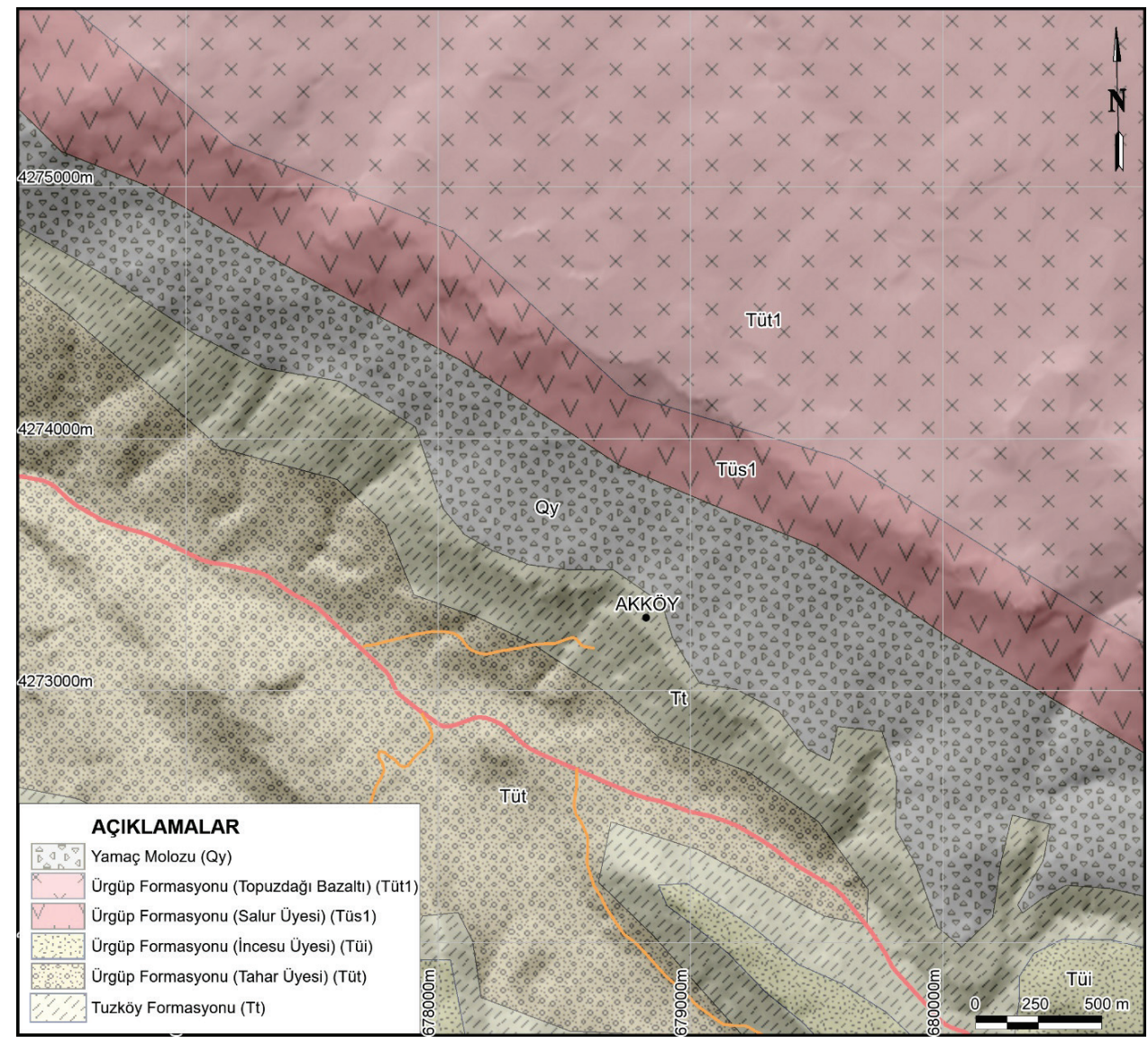

Şekil 4. İnceleme alanı jeoloji haritası (Atabey, 1989).

Figure 4. Geology map of the study area (Atabey, 1989). 
Bölgedeki Ürgüp Formasyonu Tahar üyesi (Tüt), kumlu matriks içinde yer alan pomza ve lav parçaları ile pembemsi beyaz renkli tüfit tabakalarının ardalanmasından oluşmaktadır. Üye orta - kalın tabakalı olup, toplam 80 m kalınlığındadır. Akköy'ün hemen güneydoğusunda gözlenen Tuzköy Formasyonu (Tt) sarı renkli, ince tabakalı ve laminalı, bol biyoturbasyonlu silttaşı, laminalı silisli kiltaşı, ince tabakalı ve laminalı kumtaşı ve tüfit ardalanmasından oluşmuştur (Atabey, 1989). Yamaç eğimlerinin azaldığı noktalarda yamaç molozları (Qy) gözlenmektedir.

\section{KAYA DÜŞMESI KAYNAK ZONUNDAKI DURAYSIZLIK MEKANIZMASI}

Akköy yerleşiminin kuzeydoğusunda yer alan ve yaklaşık 10-15 m yüksekliğindeki ve $80-85^{\circ}$ yamaç eğimine sahip ignimbiritler bölgedeki kaya düşmelerinin ana kaynak zonunu oluşturmaktadır. Söz konusu ignimbiritlerde soğuma etkisiyle meydana gelmiş dik ve dike yakın soğuma çatlakları göze çarpmaktadır. Yüksek devamlılığa sahip bu süreksizlikler boyunca ayrılan kaya blokları kaya düşmelerini oluşturan ana unsurdur (Şekil 5).

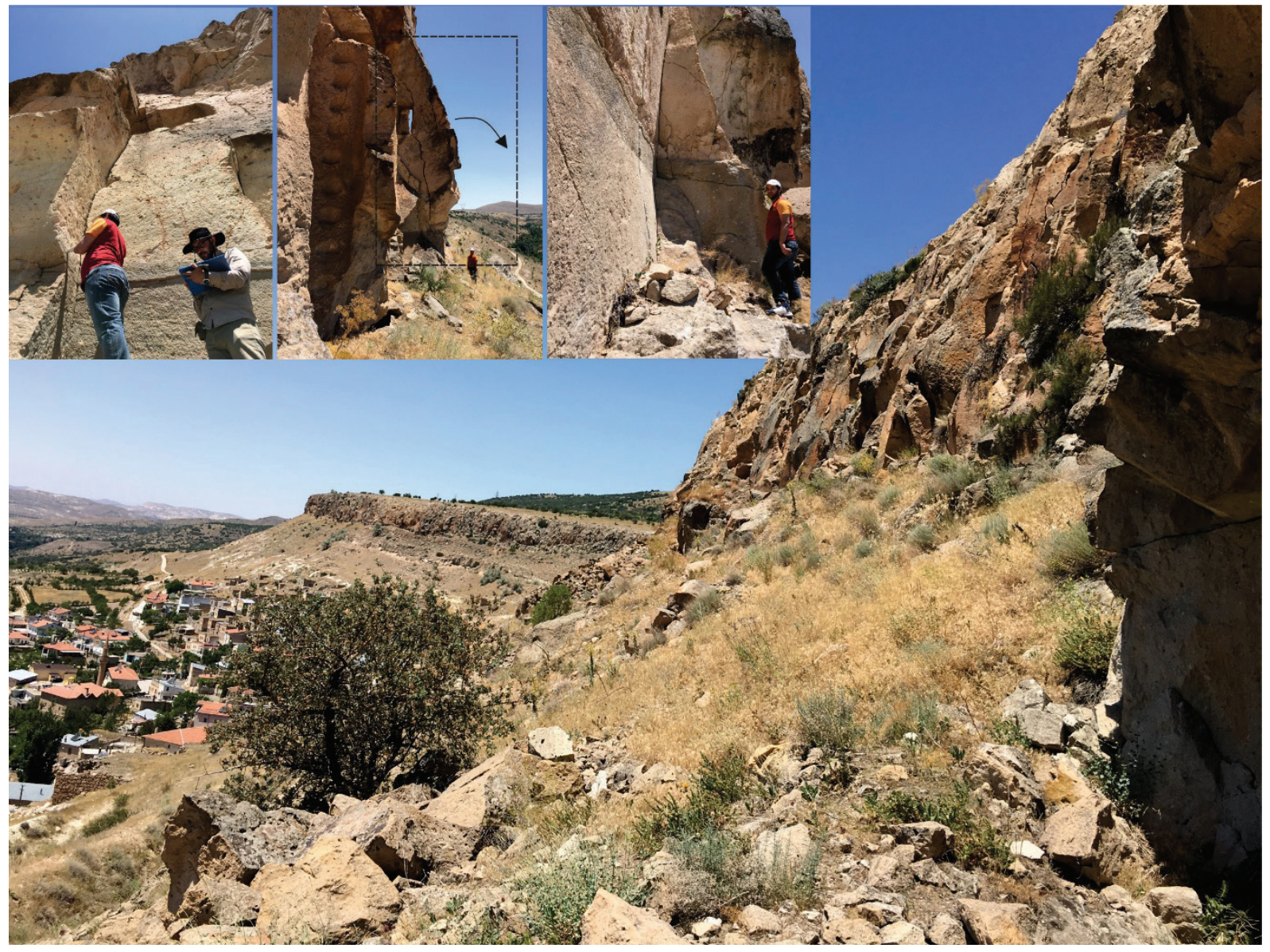

Şekil 5. Kaynak zonundaki dik süreksizlikler ve potansiyel duraysız bloklar.

Figure 5. Vertical discontinuities in the source zone and potentially unstable blocks. 
Akın, Dinçer, Orhan, Ok, Akın, Topal

Kaynak zonunda gerçekleştirilen süreksizlik hat etütleri sonucunda ignimbiritlerde $7 / 148$, $87 / 250$ ve $83 / 173$ eğim/eğim yönü değerine sahip üç egemen süreksizlik takımı belirlenmiştir. Yamaç yönelimleri genel olarak güneybatıya doğru olup, kinematik analizler için yamaç eğim/ eğim yönü 85/190 olarak alınmıştır. Araziden alınan blok numunelerden laboratuvarda silindirik karotlar alınmış ve bu karotlar üzerinde gerçekleştirilen tilt deneyleri sonucunda Barton ve Bandis (1990) yenilme ölçütü kullanılarak ignimbiritlerdeki süreksizlik sürtünme açısının $35^{\circ}$ civarında olduğu tespit edilmiştir.

İnceleme alanındaki kaynak zon için Dips v7.0 yaz1lımında (Rocscience Inc., 2019) gerçekleştirilen kinematik analizler sonucunda, ignimbiritlerde süreksizlik ve yamaç yönelimlerine bağlı olarak düzlemsel, kama ve devrilme türünde süreksizlik kontrollü yenilmelerin meydana gelme potansiyeli olduğu saptanmıştır (Şekil 6). Kinematik analizlerden elde edilen sonuçlar arazi gözlemleri ile uyum göstermekte olup, Şekil 5'teki fotoğraflarda da görüldüğü üzere birbirini kesen iki dik süreksizlik kaynak zonda kama oluşumlarına neden olmaktadır. Öte yandan, yamaç yönelimine ve eğimine yakın olan süreksizlik setine bağlı olarak düzlemsel kayma ve blok devrilmesi oluşma potansiyeli de bulunmaktadır.

\section{INCELEME ALANINDAKİ KAYA DÜŞME RİSKINIIN DEĞERLENDİRİLMESI}

Akköy (Ürgüp) yerleşiminde daha önceki yıllarda kaya düşmeleri gözlenmiş olup, bu yerleşim için kaya düşme risk durumu Saroglou vd. (2012) tarafindan yerleşim yerleri için önerilen risk sınıflaması ile değerlendirilmiştir. $\mathrm{Bu}$ kaya düşmesi risk sınıflamasında kaya düşmesi riski farklı kategoriler altında değerlendirilmiş olup, öncelikle her bir kategori için farklı ağırlık değerleri atanmıştır (Çizelge 1).

Saroglou vd. (2012) tarafindan önerilen sınıflamada A kategorisi altında şev geometrisi ve kaya düşme kaynak zonu konumu, şev pürüzlülügü, bitki örtüsü durumu gibi parametreler dikkate alınmış olup, bu parametrelerin toplam puanlamadaki (toplam puan 100 üzerinden değerlendirilmiştir) etki oran1 $\% 25^{\prime}$ tir. A grubundaki parametreler ve bu parametrelere ait sinıflama aralıkları ana sinıflama tablosu olan Çizelge 2'de sunulmaktadır. İlgili sinıflamada jeolojik yapı ve kaya düşmesinin gerçekleştiği kaya kütlesine ait özellikler B kategorisi altında incelenmiştir ve bu parametrelerin de toplam puanlamadaki etki oranı $\% 25$ 'tir. Yağış, sismik aktivite, yamaç/ şevdeki drenaj koşulları C kategorisindedir ve
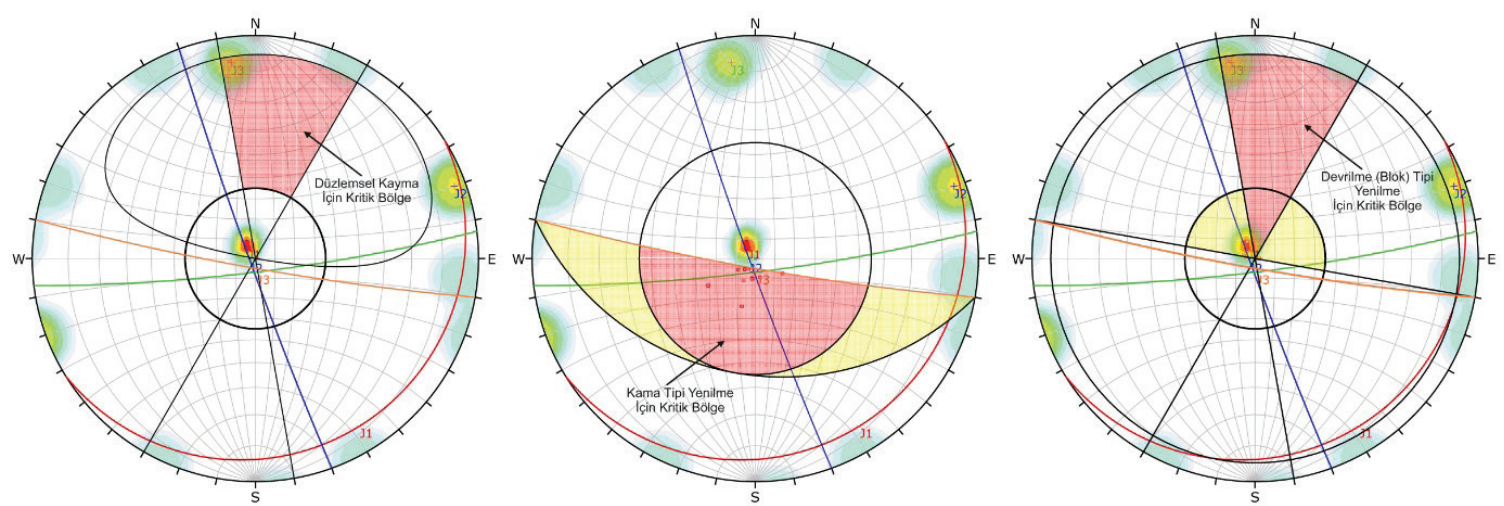

Şekil 6. Kaynak zonundaki ignimbiritler için düzlemsel, kama ve devrilme (blok) türü yenilmenin kinematik analizi. Figure 6. Kinematical analysis of planar, wedge and toppling (direct) failure for the ignimbrites at the source zone. 
Çizelge 1. Saroglou vd. (2012) tarafından önerilen kaya düşmesi risk sınıflamasında kullanılan dört parametre ve bu parametreler için atanan ağılık değerleri.

Table 1. Four parameters used for the rockfall risk classification suggested by Saroglou et al. (2012) and the weight values assigned to those parameters.

\begin{tabular}{clc}
\hline $\begin{array}{c}\text { Parametre } \\
\text { kategorisi }\end{array}$ & \multicolumn{1}{c}{ Tanımlama } & $\begin{array}{c}\text { Kategori } \\
\text { ağırlığı }\end{array}$ \\
\hline A & $\begin{array}{l}\text { Şev geometrisi ve kaya düşme kaynak zonu konumu, şev pürüzlülüğü, bitki örtüsü } \\
\text { durumu }\end{array}$ & $\% 25$ \\
B & Jeoloji ve kaya kütlesi durumu & $\% 25$ \\
C & Potansiyel tetikleyici faktörler (yağış, sismik aktivite), drenaj durumu & $\% 10$ \\
D & Sonuçları ve ilgili faktörler, kaya düşmesi geçmişi & $\% 40$ \\
\hline
\end{tabular}

kaya düşme risk sınıflamasındaki etki oranları $\% 10$ 'dur. Son olarak, kaya düşmelerinin yerleşim yeri için oluşturacağ 1 sonuçlar ve bölgede daha önceki yıllarda yaşanan kaya düşmeleri D kategorisinde değerlendirilmiş olup, en yüksek etki oranı $(\% 40)$ bu kategoriye atanmıştır.

Çizelge 2'de Akköy yerleşimi için Saroglou vd. (2012) yöntemine göre hazırlanan kaya düşmesi risk sınıflaması verilmektedir. Örneğin inceleme alanındaki yamaç açısı $85^{\circ}$ civarındadır. Buna göre, 85 derecelik şev açısı $>60^{\circ}$ (çok yüksek, askıda) sınıfına girmektedir ve bu sinifa atanan puan 100 'dür. Kategori/ parametre ağırlık faktörü bu parametre için \%A/7 (Çizelge 2'de kategori/parametre ağırlık faktörü sütunu) olarak dikkate alındığında, bu parametre için kaya düşmesi skorunun 7 olduğu $\left[\left(100^{*} 7\right) / 100=7\right]$ belirlenmiştir. A, B, C ve D kategorilerindeki farklı parametreler için yapılan değerlendirme sonucunda, tüm skor değerleri toplandığında Akköy yerleşimi için toplam kaya düşme riski puanı 49.4 olarak bulunmuştur. $\mathrm{Bu}$ değer, Saroglou vd. (2012) tarafindan önerilen ve Çizelge 3 'te sunulan risk sınıflamalarına göre "orta" derecede kaya düşmesi risk sınıfını işaret etmektedir.

Saroglou vd. (2012) tarafindan önerilen kaya düşmesi risk sinıflama sistemi yerleşim yerleri için kaya düşme riskini ortaya koymak açısından yol gösterici olmakla birlikte, önerilen iyileştirme yöntemleri oldukça geneldir ve bu yöntemlerin detay çalışmalarla ortaya konması daha gerçekçi sonuçlar verecektir. Söz konusu kaya düşmesi riski sınıflama sistemi, yerleşim yerlerinin kaya düşme riskinin belirlenmesinde uygulanabilecek bir yöntemdir. 
Çizelge 2. Akköy için Saroglou vd. (2012) yöntemine göre kaya düşme risk sinıflaması.

Table 2. The rockfall risk classification of Akköy according to Saroglou et al. (2012) method.

\begin{tabular}{|c|c|c|c|c|c|c|c|c|c|}
\hline \begin{tabular}{|l} 
Parametre \\
kategorisi
\end{tabular} & Parametre & $\begin{array}{c}\text { Kategori/Parametre } \\
\text { ağırlık faktörüi }\end{array}$ & & & Tanım & & & Puan & Skor \\
\hline \multirow[t]{9}{*}{ 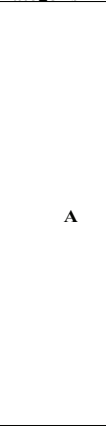 } & \multirow[t]{2}{*}{ 1. Şev açısı $\left({ }^{\circ}\right)$} & $\% \mathrm{~A} / 7$ & $25-40$ & $40-50$ (orta) & 50-60 (yüksek) & $\begin{array}{c}>60 \text { (çok yüksek, } \\
\text { askıda) }\end{array}$ & & \multirow[t]{2}{*}{100} & \multirow[t]{2}{*}{7} \\
\hline & & Puanı & 10 & 30 & 60 & 100 & & & \\
\hline & 2. Șev yüksekliği (m) & $\% \mathrm{~A} / 4$ & $<15$ & $15-30$ & $30-60$ & $>60$ & & 60 & 2.4 \\
\hline & \multirow[t]{2}{*}{$\begin{array}{l}\text { 3. Kaynak zonu yüksekliği (H } \\
\text { toplam şev yüksekliği) }\end{array}$} & $\% \mathrm{~A} / 7$ & $\begin{array}{c}\text { Şevin alt } \\
\text { kotlarnndan kaya } \\
\text { düşmeleri }(\mathrm{H} / 4)\end{array}$ & $\begin{array}{c}\text { Șevin orta } \\
\text { kotlarından kaya } \\
\text { düssmeleri }(H / 2)\end{array}$ & $\begin{array}{c}\text { Sevin orta-üst } \\
\text { kotlarından kaya } \\
\text { düşmeleri }(3 \mathrm{H} / 2)\end{array}$ & $\begin{array}{l}\text { Tüm șev yüzeyi } \\
\text { boyunca kaya } \\
\text { düşmeleri (H) }\end{array}$ & & \multirow[t]{2}{*}{60} & \multirow[t]{2}{*}{4.2} \\
\hline & & Puanı & 10 & 30 & 60 & 100 & & & \\
\hline & \multirow[t]{2}{*}{ 4. Șev pürüzlülüğü } & $\% \mathrm{~A} / 3$ & \begin{tabular}{|c} 
Pürüzlü düzlemsel \\
(sürtünme kayayı \\
yavaşlatıyor)
\end{tabular} & $\begin{array}{c}\text { Düzlemsel (kayayı } \\
\text { hızlandırıyor) }\end{array}$ & $\begin{array}{c}\text { Pürüzlü, dar } \\
\text { hendekli } \\
\text { (zıplamaya neden } \\
\text { oluyor) }\end{array}$ & $\begin{array}{l}\text { Çok pürüzlü, dar } \\
\text { hendekli }\end{array}$ & & \multirow[t]{2}{*}{60} & \multirow[t]{2}{*}{1.8} \\
\hline & & Puanı & 10 & 30 & 60 & 100 & & & \\
\hline & \multirow[t]{2}{*}{ 5. Şev yüzeyi bitki örtüsü } & $\% \mathrm{~A} / 4$ & \begin{tabular}{|c|}
$\begin{array}{c}\text { Yoğun bitki örtüsü, } \\
\text { yüksek ağaçlar }\end{array}$ \\
\end{tabular} & $\begin{array}{c}\begin{array}{c}\text { alçak bitli örtüsü, } \\
\text { calılar }\end{array} \\
\end{array}$ & Seyrek bitkiler & Bitki örtüsü yok & & \multirow[t]{2}{*}{60} & \multirow[t]{2}{*}{2.4} \\
\hline & & Puanı & 10 & 30 & 60 & 100 & & & \\
\hline \multirow{15}{*}{ B } & \multirow[t]{2}{*}{\begin{tabular}{|l|} 
6. Süreksizlik \\
pürüzlülüğ̈̈/dolgu malzemesi
\end{tabular}} & $\% \mathrm{~B} / 6$ & Pürüzlü, basamaklı & Düz, basamaklı & \begin{tabular}{|c|} 
Dalgalı veya köșeli \\
parçalar içeren \\
dolgu malzemesi, \\
pürüzlülükten \\
bağımsız veya orta \\
derecede açıklık 2.5 \\
$10 \mathrm{~mm}$
\end{tabular} & \begin{tabular}{|c|} 
Düš̈ük derecede \\
pürüzlü veya katı \\
kil dolgusu $(>5$ \\
mm), pürüzlülükten \\
bağımsız veya \\
yüksek derecede \\
açılılık $10-100 \mathrm{~mm}$
\end{tabular} & \begin{tabular}{|l|} 
Düzlemsel düz \\
veya yumuşak kil \\
dolgu (>5 mm), \\
pürüzlülükten \\
bağımsız veya \\
ÿ̈ksek derecede \\
açıklık $10-100 \mathrm{~mm}$
\end{tabular} & \multirow[t]{2}{*}{15} & \multirow[t]{2}{*}{0.9} \\
\hline & & Puanı & 10 & 15 & 30 & 60 & 100 & & \\
\hline & \multirow{2}{*}{ 7. Süreksizlik yönelimi } & $\% \mathrm{~B} / 5$ & Stabilite için uygun & Orta & Kötü & Cok kötü & & \multirow{2}{*}{100} & \multirow{2}{*}{5} \\
\hline & & Puanı & 10 & 30 & 60 & 100 & & & \\
\hline & \multirow[t]{2}{*}{ 8.Süreksizlik devamlılığı } & $\% \mathrm{~B} / 4$ & Çok düşük $(<1 \mathrm{~m})$ & Düşük (1-2 m) & Orta $(2-5 \mathrm{~m})$ & Yüksek (5-10 m) & $\begin{array}{l}\text { Çok yuksek } \\
(>10 \mathrm{~m})\end{array}$ & 100 & 4 \\
\hline & & Puanı & 10 & 15 & 30 & 60 & 100 & & \\
\hline & $\begin{array}{l}\text { 9. Süreksizlik yüzeyi tek } \\
\text { eksenli basıç dayanımı }\end{array}$ & $\% \mathrm{~B} / 1$ & $>30$ & $20-30$ & $5-20$ & $<5$, bozunmuss & & 60 & 0.6 \\
\hline & (JCS, MPa) & Puanı & 10 & 30 & 60 & 100 & & & \\
\hline & $\begin{array}{l}\text { 10. Sağlam kaya dayanımı } \\
\text { (MPa) (Düşük dayanım } \\
\text { yuvarlanan kaya bloklarının } \\
\text { parçalanmasını, yüksek } \\
\text { dayanım zıplamayı kontrol } \\
\text { eder) }\end{array}$ & $\% \mathrm{~B} / 1$ & $<10$ & $10-30$ & $30-60$ & $>60$ & & 30 & 0.3 \\
\hline & & Puanı & 10 & 30 & 60 & 100 & & & \\
\hline & $\begin{array}{l}\text { 11. Kaya kütlesi } \\
\text { blokluluğu/Blok hacmi }\left(\mathrm{m}^{3}\right)\end{array}$ & $\% \mathrm{~B} / 4$ & $<1$ & $1-2,5$ & $2,5-4$ & $4-8$ & $>8$ & 15 & 0.6 \\
\hline & & Puanı & 10 & 15 & 30 & 60 & 100 & & \\
\hline & $\begin{array}{l}\text { 12. İncelenen şev genişliği } \\
\text { boyunca daha önceden }\end{array}$ & $\% \mathrm{~B} / 2$ & Yok & $1-5$ & $5-10$ & $>10$ & & 100 & 2 \\
\hline & & Puanı & 10 & 30 & 60 & 100 & & & \\
\hline & 13. Karstlașma & $\% \mathrm{~B} / 2$ & Yok & Seyrek & Orta & Sik & & 10 & 0.2 \\
\hline & 14. Yağış koşulları ve & $\% \mathrm{C} / 3$ & Nadir & Seyrek & Mevsimsel & Sik & $\begin{array}{l}\text { Cok sık, tüm yıl } \\
\text { boyunca }\end{array}$ & 30 & 0.9 \\
\hline & & Puanı & 10 & 15 & 30 & 60 & 100 & & \\
\hline C & 15. Permeabilite/Sevdeki & $\% \mathrm{C} / 3$ & Cok yüksek & Yüksek & Orta & Düşük & Çok düşük & 30 & 0.9 \\
\hline & & Puanı & 10 & 15 & 30 & 60 & 100 & & \\
\hline & 16. Sismik tehlike (yer & $\% \mathrm{C} / 4$ & $\square * a, 16$ & $0,16<\mathrm{a}]<0,24$ & $0,2 \mathrm{a}<\mathrm{\square}<0,36$ & a $\quad \square>0,36$ & & 30 & 12 \\
\hline & ivmesi, प) a & Puanı & 10 & 30 & 60 & 100 & & & \\
\hline & 17. Kaya tutma zonunun & $\% \mathrm{D} / 10$ & $>20$ & $10-20$ & 5-10 & $2-5$ & Yok & 10 & 1 \\
\hline & & Puanı & 10 & 15 & 30 & 60 & 100 & & \\
\hline & 18. Kaya düş̧mesi geçmişi & $\% \mathrm{D} / 5$ & $\begin{array}{c}\text { Hiç - birkaç } \\
10\end{array}$ & $\begin{array}{c}\text { Nadiren } \\
15\end{array}$ & $\begin{array}{c}\text { Birçok } \\
30\end{array}$ & $\begin{array}{c}\text { Sik sık } \\
60\end{array}$ & $\begin{array}{c}\text { Devamlı } \\
100\end{array}$ & 30 & 1.5 \\
\hline D & 19. Șevin ulaşılabilirliği & $\% \mathrm{D} / 5$ & $\begin{array}{c}\text { Her türlü } \\
\text { iyileștirme yöntemi } \\
\text { uvgun }\end{array}$ & \begin{tabular}{|c|} 
İyileștirme \\
$\begin{array}{c}\text { yöntemlerinin çoğu } \\
\text { uygun }\end{array}$
\end{tabular} & $\begin{array}{l}\text { İyileştirme } \\
\text { yöntemlerinin } \\
\text { birkacıı uvgun }\end{array}$ & \begin{tabular}{|c|} 
İyileștirme \\
yöntemlerinin çok \\
azı uvgun
\end{tabular} & $\begin{array}{l}\text { Şeve ulaşım çok } \\
\text { zor }\end{array}$ & 10 & 0.5 \\
\hline & & Puanı & 10 & 15 & 30 & 60 & 100 & & \\
\hline & $\begin{array}{l}\text { 20. Carpmanın potansiyel } \\
\text { sonuçları ve yapıların değeri }\end{array}$ & $\% \mathrm{D} / 20$ & $\begin{array}{c}\text { İhmal edilebilir; } \\
\text { insan yapısı ve } \\
\text { daimi aktivitesi } \\
\text { mevcut değil }\end{array}$ & $\begin{array}{l}\text { Düşük; insan } \\
\text { aktivitesi az bir } \\
\text { bölgede }\end{array}$ & $\begin{array}{c}\text { Insan aktivitesi orta } \\
\text { derecede; düşük } \\
\text { sıklıkta evler }\end{array}$ & $\begin{array}{c}\text { Yüksek; sik insan } \\
\text { mevcudiyeti; birçok } \\
\text { ev }\end{array}$ & \begin{tabular}{|c|} 
Cok yüksek; \\
devamlı insan \\
mevcudiyeti; yoğun \\
verlesim
\end{tabular} & 60 & 12 \\
\hline & & Puanı & 10 & 15 & 30 & 60 & $\frac{100}{100}$ & & \\
\hline & & & TOPLAM SKOR & (EN FAZLA 100) & & & & & 49.4 \\
\hline & & & KAYA DÜŞME & Sİ RISK SINIFI & & & & & Orta \\
\hline
\end{tabular}


Çizelge 3. Saroglou vd. (2012) risk sınıflamasında risk sınıfı açıklamaları ve önerilen iyileştirme yöntemleri. Table 3. Risk class definitions of Saroglou et al. (2012) risk classification and suggested stabilization methods.

\begin{tabular}{|c|c|c|c|}
\hline $\begin{array}{l}\text { Risk } \\
\text { sinıfi }\end{array}$ & $\begin{array}{l}\text { Toplam ağırlıklı } \\
\text { skor }(1-100)\end{array}$ & Risk & $\begin{array}{l}\text { Önerilen koruma yöntemleri } \\
\text { (seçim sahaya özgüdür) }\end{array}$ \\
\hline I & $<20$ & Çok düşük & Gerekli değil, seyrek yerel müdahaleler mümkün \\
\hline II & $21-40$ & Düşük & Sinırlı boyutta \\
\hline III & $41-60$ & Orta & $\begin{array}{l}\text { Basit önlemler (örneğin bulonlar, ağlar, duraysız blokların } \\
\text { temizlenmesi, basit hafif bariyerler) }\end{array}$ \\
\hline IV & $61-80$ & Yüksek & $\begin{array}{l}\text { Aktif (örneğin bulonlar, ankrajlar) ve pasif (örneğin ağlar, tel } \\
\text { halat kablolar, dayanma yapıları, bariyerler ve duraysız blokların } \\
\text { temizlenmesi) önlemlerin kombinasyonu }\end{array}$ \\
\hline V & $81-100$ & Çok yüksek & $\begin{array}{l}\text { Duraysızlık kritik durumda, yaygın ve/veya dayanımı yüksek aktif } \\
\text { ve pasif yöntemlerin kombinasyonu. Önleme rağmen bir miktar risk } \\
\text { göz önüne alınmalıdır. }\end{array}$ \\
\hline
\end{tabular}

\section{3-BOYUTLU KAYA DÜŞME ANALIZLERI}

Akköy yerleşimi eğimli bir yamaç üzerine kurulmuştur. Üst kotlarda dike yakın bir topoğrafya sunan ignimbiritlerdeki düşey soğuma çatlakları boyunca kopan bloklar yamaç aşağ1 doğru kaya düşme problemine neden olmaktadır. $\mathrm{Bu}$ blokların boyutlarının arazi gözlemleri ve ölçümleri sonucunda yer yer 2m'yi bulabildiği belirlenmiştir. Önceki yıllarda bölgede kaya düşmesi nedeniyle olumsuzlukların yaşandığ1 yerleşim sakinleri tarafindan belirtilmektedir. 2012 y1lında kaya tutma hendeğinin yapımından sonra 2019 y1lına kadar herhangi bir kaya düşme problemi yaşanmadığı da yine yerli halk tarafından ifade edilmektedir. Kaya düşmelerinin Akköy için risk yaratmaması amacıyla inşa edilen $2 \mathrm{~m}$ derinliğindeki hendeğin yeterli olup olmadığı, bu çalışma kapsamında yapılan 3-boyutlu kaya düşmesi analizleri ile ortaya konmuştur.

Akköy yerleşim yerinin 3-boyutlu sayısal yüzey modelleri insansız hava aracı (İHA-multikopter) ile alınan fotogrametrik görüntülerden, görüntü işleme yöntemi ile elde edilen yaklaşık $3 \mathrm{~cm}$ yersel çözünürlüklü nokta bulutlarından oluşturulmuştur. 3-boyutlu kaya düşme analizleri RocPro3D (RocPro3D, 2014) 3-boyutlu kaya düşme analiz yazılımı ile gerçekleştirilmiştir. Akköy yerleşimi için İHA görüntüsünden elde edilen nokta bulutu yardımıyla RocPro3D yazılımında oluşturulan ve 3-boyutlu kaya düşme analizlerinin altlığını oluşturan sayısal yüzey modelinden üretilen düzensiz üçgen ağ 1 (TIN) ve buna ait yükseklik modeli Şekil 7'de sunulmuştur. 
Akın, Dinçer, Orhan, Ok, Akın, Topal

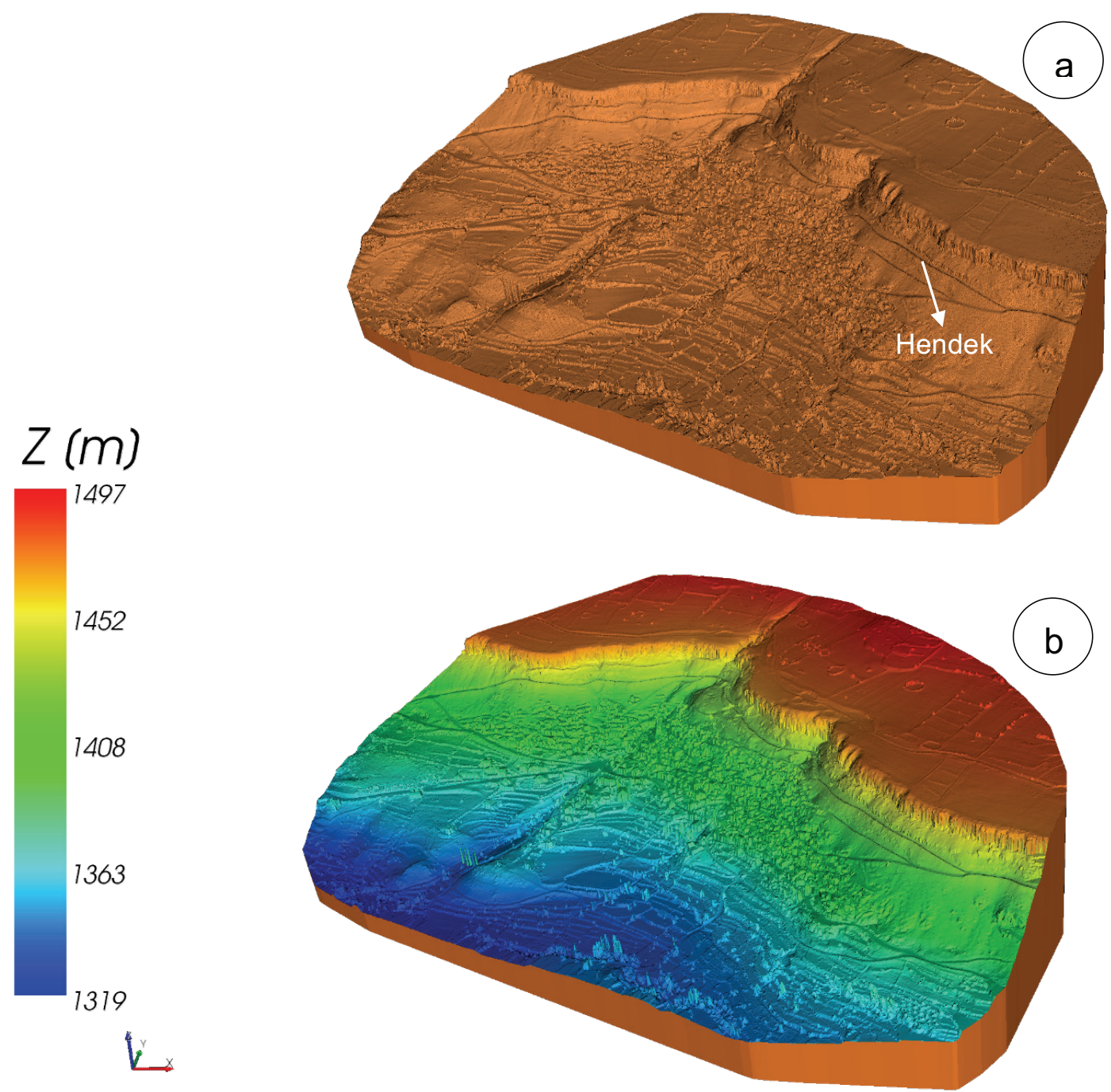

Şekil 7. RocPro3D yazılımında İHA verisi kullanılarak oluşturulan sayısal yüzey modeli (a) düzensiz üçgen ağı (TIN) ve (b) yükseklik modeli.

Figure 7. Digital surface model (a) triangulated irregular network (TIN) (b) elevation model constructed in RocPro3D software using UAV data.

Şekil 7'den görüleceği üzere inceleme alanındaki deniz seviyesinden yükseklik 1319 ile $1497 \mathrm{~m}$ arasında değişmektedir. Kaya düşme kaynak lokasyonunu oluşturan ve dik bir topoğrafya $\left(80-90^{\circ}\right)$ sunan ignimbiritlerin en yüksek kotu ise $1465 \mathrm{~m}$ civarındadır. Bu nedenle 3-boyutlu kaya düşme analizlerinde, en olumsuz koşulu yansıtmak açısından, bloklar kaynak zonun en üst seviyesinden (1465 m kotundan) geçen bir hat boyunca düşürülmüştür.

RocPro3D yazılımında kaya düşmesinin modelleneceği 3-boyutlu sayısal yüzey modeli üzerine farklı jeolojik birimler tanımlanabilmekte ve bu birimler için farklı geri verme 
katsayıları (Rn ve Rt) ve sürtünme katsayıları atanabilmektedir. Akköy yerleşiminde, kaya düşmelerinin gerçekleştiği bölgede arazi gözlemlerine bağl1 olarak 3 ana jeolojik birim ayırtlanmıştır. Buna göre, $1319 \mathrm{~m}$ ile yaklaşı 1355 m kotları arasında yamaç molozu, 1355 $\mathrm{m}$ ile $1435 \mathrm{~m}$ arasinda volkanosedimanter birimler (tüf ve sedimanter özellikteki gölsel çökellerin ardalanması) ve 1435 m kotundan sonra ise kaynaklaşmış ignimbirit birimi yer almaktadır. Arazide daha önceden düşen blokların konumlarına bağlı olarak yapılan geri analizler ve literatür verilerine bağlı olarak Akköy yerleşiminin 3-boyutlu kaya düşme analizlerinde kullanılan parametreler Çizelge 4 'te özetlenmiştir.

RocPro3D yazılımında Akköy yerleşimi için İHA verisinden elde edilmiş sayısal yüzey modeli üzerinde gerçekleştirilen 3-boyutlu kaya düşme analizlerinde, düşen blokların (ignimbirit) birim hacim ağırlığı laboratuvar deney sonuçlarına göre $1760 \mathrm{~kg} / \mathrm{m}^{3}$ olarak belirlenmiş olup, analizlerde $2 \mathrm{~m}$ boyutundaki 5000 adet blok
1465 m kotundan düşürülmüştür. 3-boyutlu kaya düşme analizlerinden elde edilen yuvarlanma hatları Şekil 8'de sunulmuştur.

Şekil 8'de sunulan kaya düşme hatları (kırmızı hatlar) incelendiğinde, yuvarlanan blokların önemli bir bölümünün kaya tutma hendeği tarafindan tutulduğu görülmektedir. Ancak, yerleşimin kuzeybatısında ve güneydoğusunda kalan bölgelerde bir kısım bloğun hendek yapısını aşarak yamaç aşağı kotlara doğru ilerleyebileceği tespit edilmiştir. Öte yandan, 1 km'lik hendeğin orta bölümündeki yerleşimin yoğun olduğu bölgenin hemen üstünde de bazı bloklar hendeği aşıp yerleşim yerine kadar ulaşabilmektedir. 3-boyutlu kaya düşme analiz sonuçları dikkate alındığında, kaya düşmelerinin önlenmesi amacıyla açılmış olan hendek yapısının ilgili yerleşim yeri için kaya düşme riskini tamamen ortadan kaldıramadığ ve özellikle büyük boyutlu blokların (örn. 2m) kaya tutma hendeğini aşabileceği sonucuna varılmıştır.

Çizelge 4. RocPro3D yazılımında 3-B kaya düşme analizleri için kullanılan parametreler.

Table 4. Parameters of 3-D rockfall analyses in RocPro3D software.

\begin{tabular}{lccc}
\hline Birim & $\begin{array}{c}\text { Normal geri verme } \\
\text { katsayısı (Rn) }\end{array}$ & $\begin{array}{c}\text { Tanjant geri verme } \\
\text { katsayısı (Rt) }\end{array}$ & Sürtünme katsayısı (k) \\
\hline İgnimbirit & 0.78 & 0.77 & 0.35 \\
Volkanosedimanter birim & 0.73 & 0.71 & 0.45 \\
Yamaç molozu & 0.50 & 0.70 & 0.60 \\
\hline
\end{tabular}




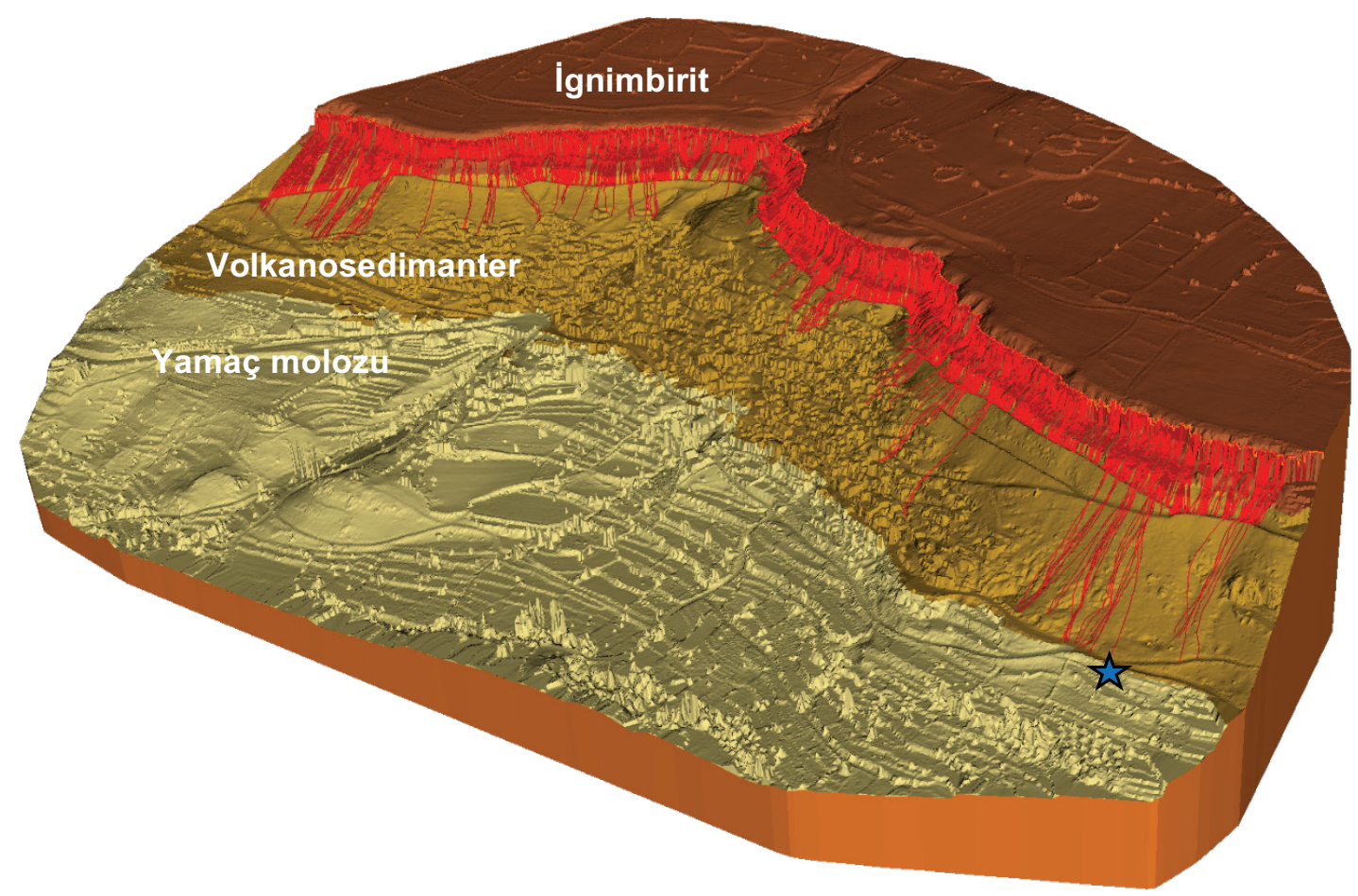

Şekil 8. RocPro3D yazılımında gerçekleştirilen 3-B kaya düşme analizi ile belirlenen yuvarlanma hatları. Figure 8. Rockfall trajectories determined by 3-D rockfall analysis performed in RocPro3D software.

RocPro3D yazılımı ile gerçekleştirilen 3-boyutlu kaya düşme analizlerinde, düşen blokların sıçrama yükseklikleri, kinetik enerjileri ve hızları da belirlenmiştir. Buna göre, her bir kaya düşme hattı için hesaplanan sıçrama yüksekliği, kinetik enerji ve hareket hızı yine 3 boyutlu model üzerinde sırasıyla Şekil 9, 10 ve 11'de sunulmuştur. Şekil 9'da sunulan sıçrama yükseklik haritasına göre, yaklaşı $10 \mathrm{~m}$ yükseklikteki dik yamaçtan serbest düşmelerini yapan bloklardaki sıçrama yükseklikleri hendek yapısından sonra çoğunlukla 2 m'nin altındadır. Ancak bazı bölümlerde sıçrama yükseklikleri 4.5 - 5 m'ye (blok boyutu olan $2 \mathrm{~m}$ dahil) ulaşabilmektedir.

İnceleme alanında düşen kaya bloklarının toplam kinetik enerjilerine bakıldığında (Şekil
10), kaya tutma hendek yapısının gerisindeki dik yamaç boyunca 300 kJ'un üzerinde kinetik enerjiye sahip olan blokların bulunduğu görülmektedir. Hendek yapısından yamaç aşağı olan bölümde ise düşen blokların kinetik enerjileri azalmakta ve kinetik enerji değerleri 30 ile $300 \mathrm{~kJ}$ arasında değişmektedir.

RocPro3D3-boyutlu kaya düşme yazılımının en önemli avantajlarından biri de 3-boyutlu analizler ile belirlenen kaya düşme hatlarının 2-boyutlu kesitler üzerinde incelenmesine olanak sağlamasıdır. $\mathrm{Bu}$ kesitler üzerinde, yuvarlanan blokların hareketleri sırasındaki sıçrama yüksekliği, kinetik enerji, yuvarlanma hızı vb. gibi özelliklerindeki değişim mesafeye bağlı olarak değerlendirilebilmektedir. 


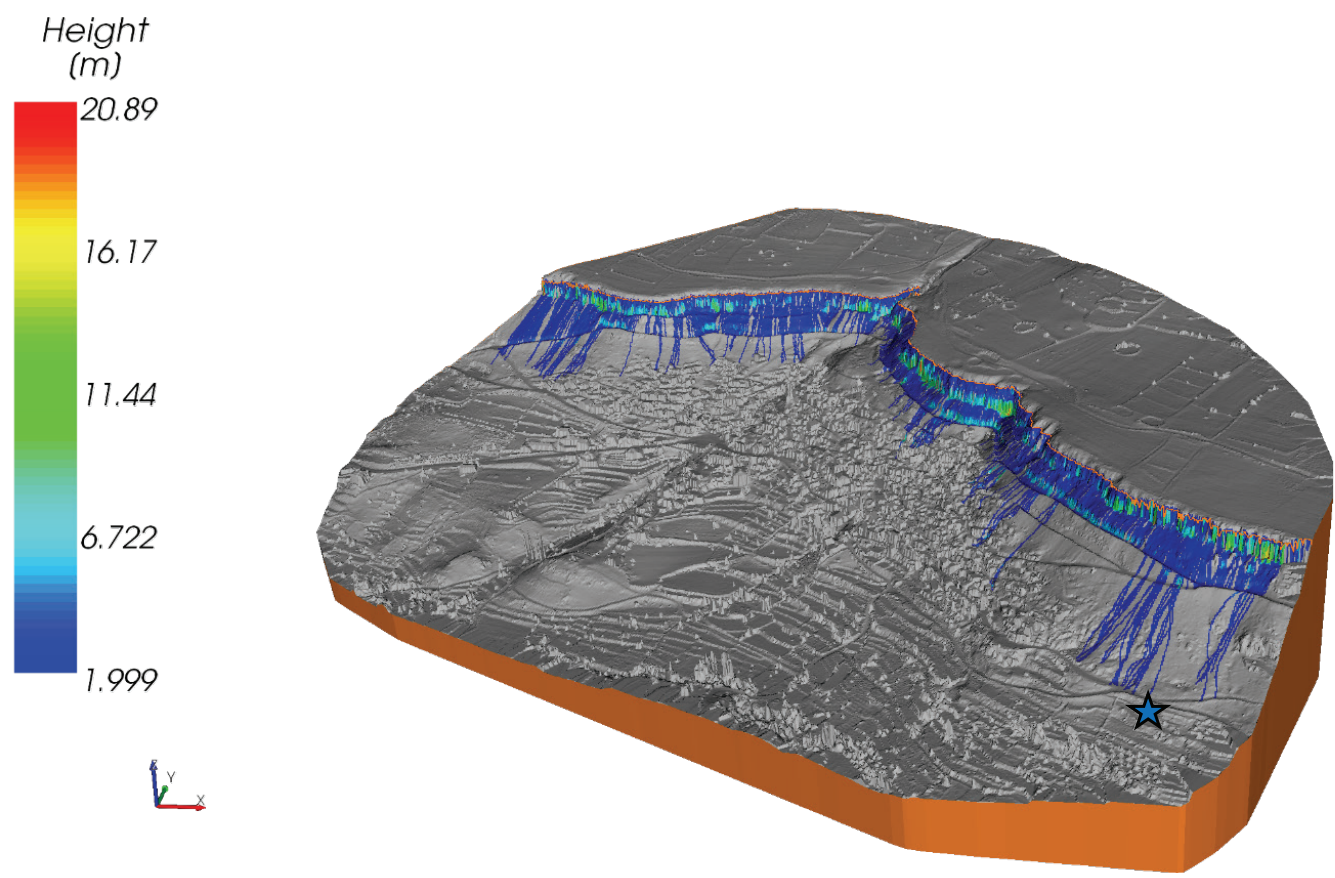

Şekil 9. Düşen kaya bloklarının sıçrama yüksekliği dağılımı.

Figure 9. Bounce height variation of falling rocks.
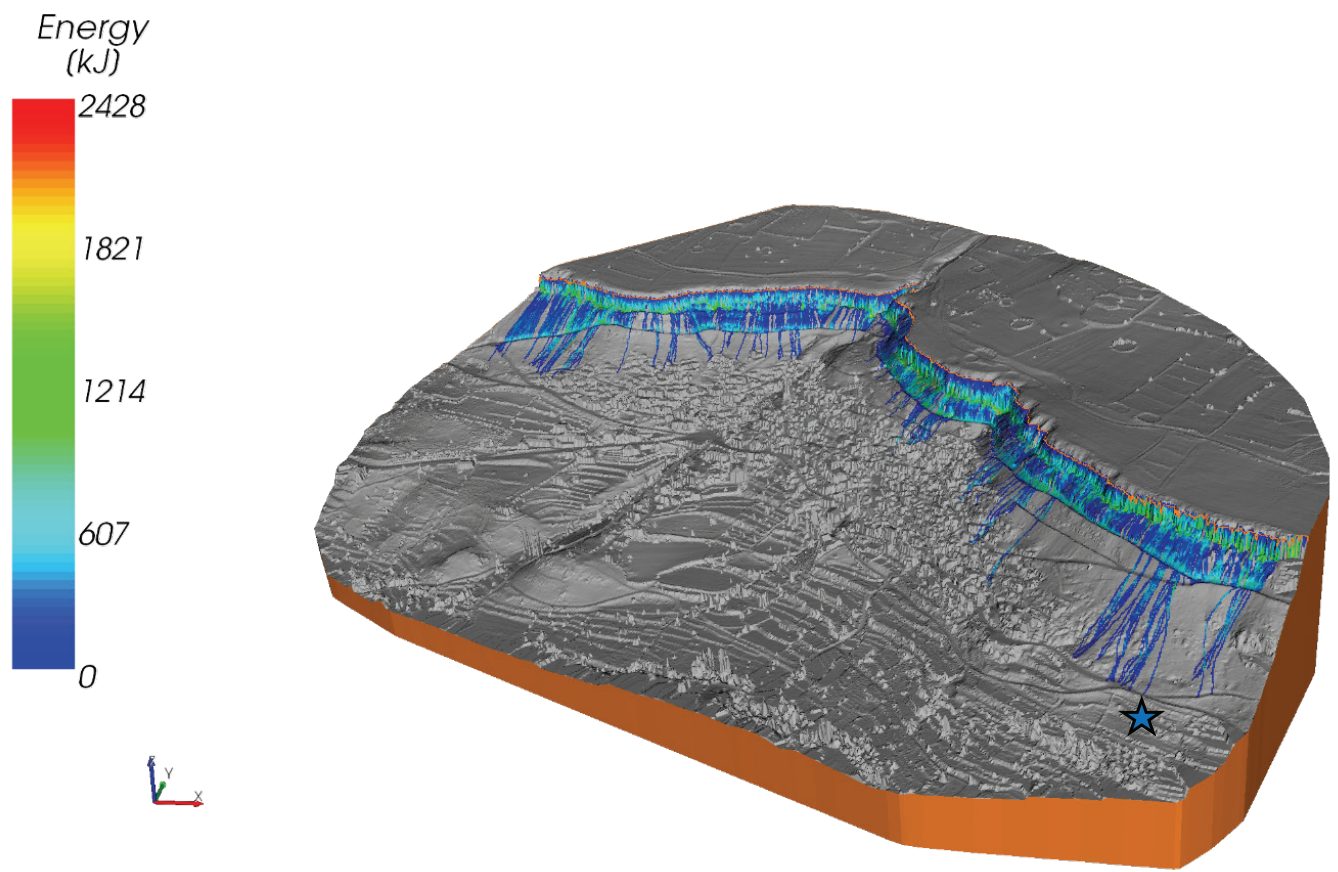

Şekil 10. Düşen kaya bloklarının toplam kinetik enerjisi dağılımı.

Figure 10. Total kinetic energy variation of falling rocks. 
Akın, Dinçer, Orhan, Ok, Akın, Topal

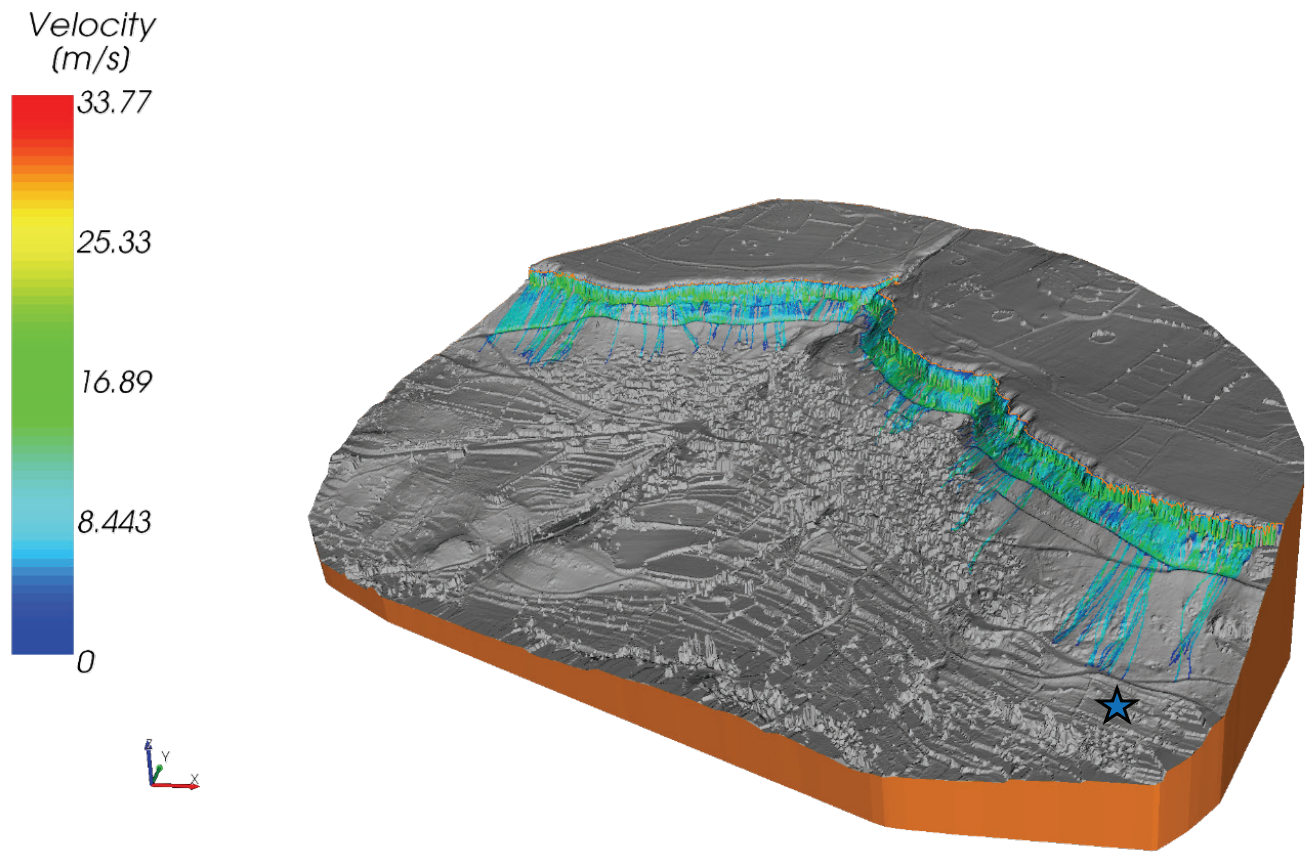

Şekil 11. Düşen kaya bloklarının hareket hızı dağılımı.

Figure 11. Motion velocity variation of falling rocks.

İnceleme alanının güneydoğusuna doğru kaya tutma hendeğini aşan bir bloğun (Şekil $8,9,10$ ve 11 'deki modeller üzerinde mavi yıldız ile gösterilen 4628 nolu yuvarlanma hattı) hareketi sırasındaki sıçrama yüksekliği ve kinetik enerji değerlerindeki değişimi gösteren 2-boyutlu kesitler Şekil 12'de verilmiştir. 138.4 m maksimum yuvarlanma mesafesine sahip olan bu blok, $1465 \mathrm{~m}$ kotundan itibaren ilk serbest düşüşünden sonra hendeği aşarken yaklaşık 6.5 m'lik (blok çapı olan $2 \mathrm{~m}$ dahil) bir sıçrama yüksekliğine ulaşmıştır. Kaya tutma hendeğini aştıktan sonra, blok hareketine çoğunlukla yuvarlanarak devam etmiştir (Şekil 12-a). Öte yandan, söz konusu bloğun kinetik enerjisi dik yamaçtan düşümü esnasında $700 \mathrm{~kJ}$ civarındadır. 2 m'lik hendeği aşarken bloğun toplam kinetik enerjisi $800 \mathrm{~kJ}$ mertebesine yükselmektedir. Blok yamaç aşağı hareketine devam ederken, toplam kinetik enerjisi sönümlenmektedir (Şekil 12-b).
İHA verisinden üretilen sayısal yüzey modeli kullanılarak gerçekleştirilen 3-boyutlu kaya düşme analizleri sonucunda belirlenen kaya düşme hatları, yine İHA uçuşları sonrasında ham görüntülerden elde edilen gerçek ortogörüntü mozaiği üzerine aktarılmıș ve inceleme alanındaki kaya düşmelerinin yerleşim yeri için oluşturacağı tehlikenin boyutları ortaya konmuştur. Şekil 13'te sunulan gerçek ortogörüntü mozaiği incelendiğinde, kaya tutma hendeğini aşan blokların çoğunun yerleşimin hemen üst bölümünde durduğu görülmektedir. Hendeği aşan $2 \mathrm{~m}$ çapındaki bloklar herhangi bir engele çarparak durabilmekte veya yön değiştirmektedir (Şekil 13-a). Diğer taraftan, Akköy'ün güneydoğusundaki bir bölümde ise yuvarlanan bloklar, yerleşimin iç kesimlerine kadar ulaşabilmektedir (Şekil 13-b). 3-boyutlu kaya düşme analiz sonuçları, Akköy yerleşiminin bir bölümünün, üst kotlardaki $2 \mathrm{~m}$ derinliğindeki hendek yapısına rağmen halen kaya düşme tehlikesi altında olduğunu göstermektedir. 

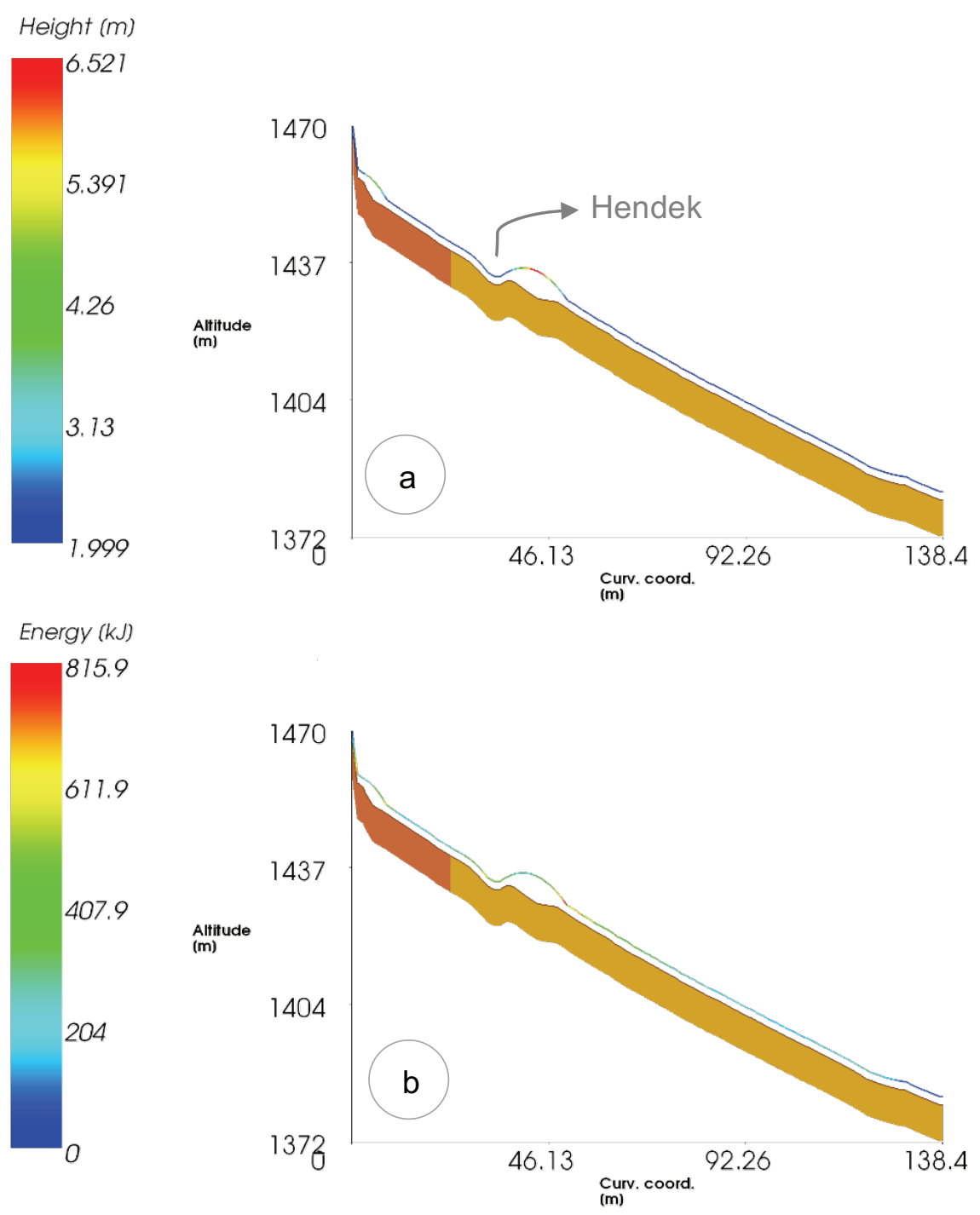

Şekil 12. 4628 nolu kaya düşme hattına ait sıçrama yüksekliği ve toplam kinetik enerji kesitleri.

Figure 12. Cross-sections of bounce height and total kinetic energy for the rockfall trajectory 4628.

3-boyutlu kaya düşme analizlerinin ve bu analizlerde kullanılan sayısal yüzey modeli çözünürlüğünün kaya düşme hatlarının yönelimi ve yuvarlanma mesafeleri üzerindeki etkisi Şekil 13'te sunulan gerçek ortogörüntülerde belirgin şekilde ortaya çıkmaktadır. 2-boyutlu kaya düşme analizlerinde kaya düşmeleri sırasındaki topoğrafyaya bağlı sapmaları gözlemlemek mümkün değildir. Oysa kaya düşmeleri sonucu hareket halindeki bloklar topoğrafik düzensizlikler ve/veya insan yapımı engeller (bina, duvar, çit vb.) nedeniyle yön değiştirebilmekte veya hareketlerini sonlandirabilmektedir. $\mathrm{Bu}$ nedenle 3-boyutlu kaya düşme analizleri daha gerçekçi sonuçlar sunmaktadirlar. 
Akın, Dinçer, Orhan, Ok, Akın, Topal
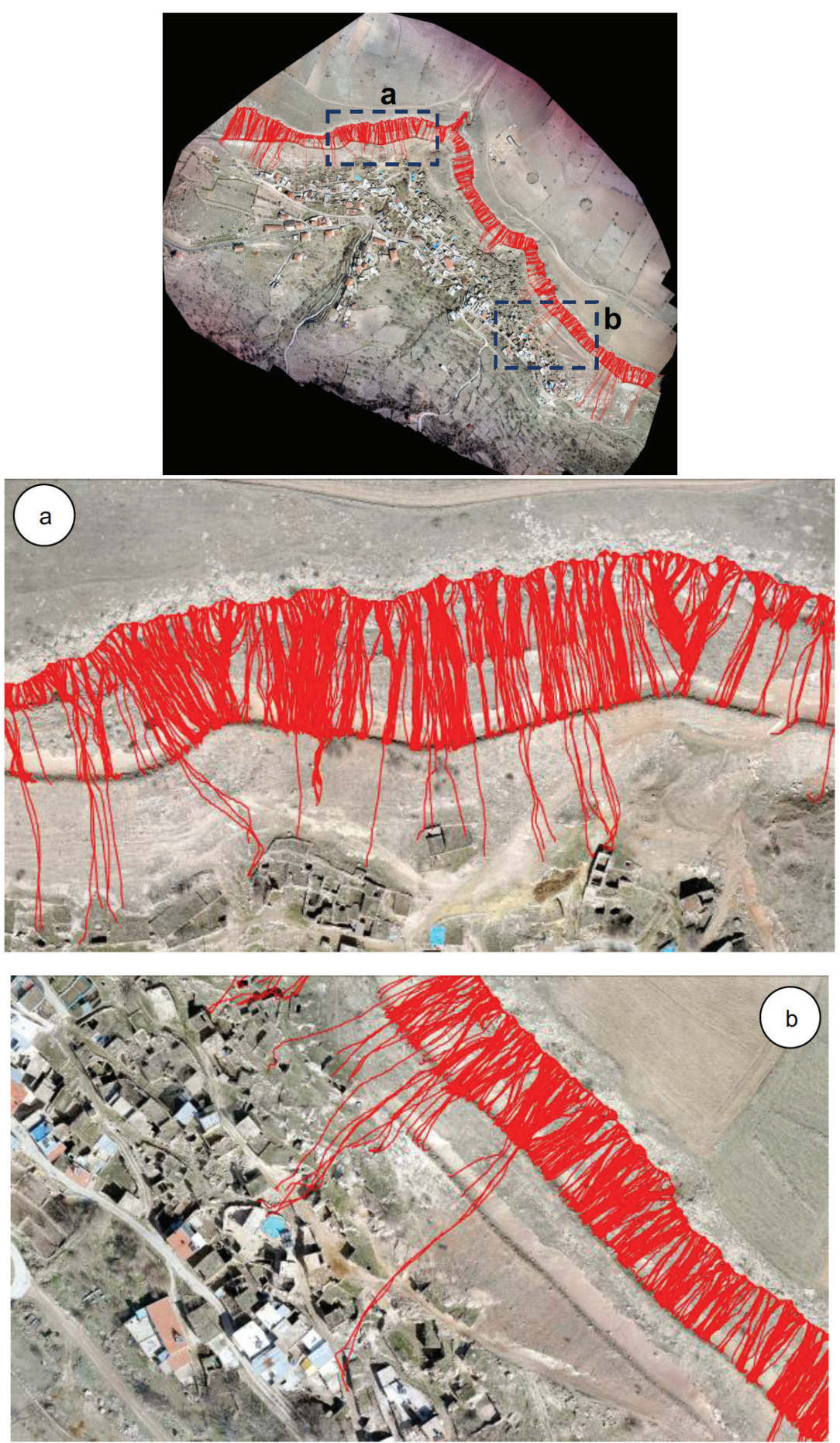

Şekil 13. Kaya düşme hatlarının gerçek ortogörüntü mozaiği üzerindeki yakın görünümleri. Figure 13. Views of rockfall trajectories on true orthoimage mosaic. 


\section{SONUÇLAR}

Kaya düşme tehlikesi altında olan alanlarda kayadüşmelerininiyileştirilmesiiçinçeşitliönleme ve koruma yöntemleri uygulanabilmektedir. $\mathrm{Bu}$ yöntemler arasında kaya tutma hendekleri veya alanları küçük yerleşim yerlerinde ekonomik ve kolay yapılabilirlik açısından sıklıkla tercih edilmektedir. Ancak, doğru projelendirilmeyen kaya tutma hendeklerinde kaynak zonundan kaya düşmesinin devam etmesi durumunda, düşen bloklar hendeği aşarak tehlike yaratmaya devam edebilmektedir. Bu çalışma kapsamında Akköy (Ürgüp) yerleşiminde 2012 yılında kaya düşmelerinden yerleşimi korumak amacıyla inşa edilen $2 \mathrm{~m}$ derinliğindeki ve yaklaşı 1 $\mathrm{km}$ uzunluğundaki kaya tutma hendeğinin performans1 3-boyutlu kaya düşme analizleri ile incelenmiştir. Bu tür uzun kaya düşmesi koruma yapılarının tasarımında 3-boyutlu kaya düşmelerinden faydalanılması sonuçların daha gerçekçi elde edilmesine imkan sağlamaktadır. Öte yandan, topoğrafik değişkenliklere bağlı olarak belirli kesit hatları boyunca yapılan 2-boyutlu kaya düşme analizlerinde düşen blokların yanal yön değişimlerini belirlemek mümkün olamamaktadır. Bu nedenle 3-boyutlu kaya düşme analizleri bu açıdan da önemli bir avantaj sunmaktadir.

Çalışma alanı için gerçekleştirilen 3-boyutlu kaya düşme analizleri sonucuna göre Akköy yerleşiminin üst kotlarında inşa edilen $2 \mathrm{~m}$ derinliğindeki kaya tutma hendeğinin bazı bölümlerde kaya düşmelerini önlemede yetersiz kaldığ1 ve hendeği aşan blokların yerleşim yerine kadar ulaşabildiği belirlenmiştir. İnceleme alanında yüksekliği 10 ile $15 \mathrm{~m}$ arasında değişen kaynak zonunda yüksek devamlılığa sahip soğuma çatlakları boyutları 2 m'yi geçebilecek blokların oluşumuna neden olabilmektedir. $\mathrm{Bu}$ nedenle, çalışma alanında inşa edilen hendek derinliği ile maksimum blok çapı birbirine çok yakındır. 3-boyutlu kaya düşme analizlerince de doğrulandığı üzere, düşen blokların hendek bölgesindeki ufak sıçramaları bile bloğun hendeği kolaylıkla aşmasını sağlayacaktır. Bu nedenle, inşa edilen hendeğe rağmen Akköy yerleşimi kısmen de olsa kaya düşme tehlikesi altındadır. Bununla birlikte, kaya tutma hendeğinin uzun dönem içerisinde düşen kaya bloklarınca dolması ve periyodik bakımının (blok temizliği) yapılmaması durumunda tehlikenin boyutu daha da artacaktır.

3-boyutlu kaya düşme analizlerinde oldukça yüksek çözünürlüklü sayısal yüzey modellerine ihtiyaç duyulmaktadır. Bu amaçla yersel lazer tarama (TLS) veya insansiz hava araçları ile alınan fotogrametrik görüntülerin işlenmesinden elde edilen nokta bulutları son yıllarda yaygın olarak kullanılmaya başlanmıştır. Ancak hendek, vadi vb. gibi derin topoğrafik düzensizliklerin bulunduğu lokasyonlarda TLS yöntemiyle oluşturulan nokta bulutlarının bu tür düşey yapıları tam ve gerçekçi olarak yansıtmakta zorlanabilmesine bağlı olarak, kaya düşmesi sonrası yuvarlanma rotalarının tam belirlenememesinin, kaya düşme analizi sonuçları üzerinde önemli bir etkisi olabilmektedir. Çünkü TLS yönteminde, kaynak zondan çok daha düşük kotlarda konumlandırılan ölçüm aletinden gönderilen lazer 1şınları, topoğrafya üzerindeki düşey düzensizlikleri ortaya çıkaramamaktadır. $\mathrm{Bu}$ tür durumlarda topoğrafyadaki düşey yapıların sayısal yüzey modelinde ortaya çıkarılabilmesi için TLS ölçümlerinin en az bir ters açıdan tekrar yapılması gerekmektedir. Ancak bu inceleme alanında olduğu gibi, hendek türü yapıların oldukça uzun olması durumunda bu işlemin oldukça zaman alması ve zahmetli olması durumu söz konusudur. $\mathrm{Bu}$ nedenle insansız hava araçlarıyla alınan fotogrametrik görüntüler ile daha kapsamlı ve oldukça fazla 
Akın, Dinçer, Orhan, Ok, Akın, Topal

detay içeren bir sayısal yüzey modelini hızlı bir şekilde oluşturmak ve devamında işlemek mümkün olmaktadır.

Sonuç olarak, gerçekleştirilen bu çalışma kapsamında yerleşimin orta derecede kaya düşme riski altında olduğu belirlenmiştir. $\mathrm{Bu}$ kapsamda, Saroglou (2012) tarafindan önerilen kaya düşme riski sinıflamasında bu tür alanlar için basit kaya düşmesi önlemlerinin yeterli olabileceği ifade edilmesine rağmen, doğru tasarlanmayan bu önlemler neticesinde kaya düşmeleri yerleşimler için halen risk teşkil etmeye devam edecektir. Bu nedenle, kaya tutma hendeklerinin tasarımında öncelikle bölgeye özel kaya düşme modellemeleri gerçekleştirilerek, düşen kaya bloklarının darbe noktaları ve sıçrama yükseklikleri belirlenmeli, tutma hendeğinin lokasyonu, derinliği ve genişliği bu analizler sonucunda ortaya konmalidir.

\section{KATKI BELIRTME}

$\mathrm{Bu}$ çalışma, UDAP-G-16-03 numaralı proje ile Afet ve Acil Durum Yönetimi (AFAD) Başkanlığg'nca desteklenmiştir. Projeyi destekleyen ilgili kuruma teşekkür ederiz. Bununla birlikte AFAD, Planlama ve Risk Azaltma Dairesi Başkanlığı'ndan H. Gürhan İlgen ve Ahmet Demir'e teşekkürlerimizi sunariz.

\section{KAYNAKLAR}

Atabey, E., 1989. MTA Genel Müdürlüğü, 1/100.000 Ölçekli Türkiye Jeoloji Haritaları, Kayseri H19 (K33) Paftas1, 18 syf.

Barton, N., Bandis, S. C., 1990. Review of predictive capabilities of JRC-JCS model in engineering practice. Proceedings of the International Symposium on Rock Joints, Loen, Norway, 603610.
Dinçer, İ., Orhan, A., Frattini, P., Crosta, G.B., 2016. Rockfall at the heritage site of the Tatlarin Underground City (Cappadocia, Turkey). Natural Hazards, 82 (2), 1075-1098.

Fanos, A.M., Pradhan, B., 2019. A novel rockfall hazard assessment using laser scanning data and 3D modelling in GIS, Catena, 172, 135-150.

FHWA, 1989. Rock Slopes: Design, Excavation and Stabilization. Publication FHWA-TS-89-045. Turner-Fairbank Highway Research Center, McLean.

Gökçe, O., Özden, S., Demir, A., 2008. Türkiye'de afetlerin mekansal ve istatistiksel dağılımı afet bilgileri envanteri. Bayındırlık ve İskan Bakanlığı Afet İşleri Genel Müdürlüğü Afet Etüt ve Hasar Tespit Dairesi Başkanlığı, Ankara, 112 sf.

Kayabaș1, A., 2018. The assessment of rockfall analysis near a railroad: a case study at the Kızılinler village of Eskişehir, Turkey. Arabian Journal of Geosciences, 11: 800.

Pierson, L.A., Gullixson, C.F., Chassie, R.G., 2001. Rockfall Catchment Area Design Guide. Final Report SPR-3(032) Oregon Department of Transportation, Salem.

Ritchie, A.M., 1963. Evaluation of rockfall and its control. Highw Res Board Rec 17, 13-27.

RocPro3D, 2014. RocPro3D software. http://www. rocpro3d.com/rocpro3d_en.php.

Rocscience Inc., 2019. https://www.rocscience.com/ help/dips/ Erişim tarihi: 08.04.2019.

Saroglou, H., Marinos, V., Marinos, P., Tsiambaos, G., 2012. Rockfall hazard and risk assessment: an example from a high promontory at the historical site of Monemvasia, Greece. Natural Hazards Earth System Sciences, 12, 1823-1836.

Sarro, R., Riquelme, A., García-Davalillo, J.C., Mateos, R.M., Tomás, R., Pastor, J.L., Cano, M., Herrera, G., 2018. Rockfall simulation based on UAV photogrammetry data obtained during an emergency declaration: application at a cultural heritage site. Remote Sensing, 10, 1923; doi:10.3390/rs10121923. 
Topal, T., Akin, M. K., Ozden, A.U., 2007. Assessment of rockfall hazard around Afyon Castle. Environmental Geology, 53(1):191-200.

Topal, T., Akın, M.K., Akın, M., 2012. Rockfall hazard analysis for an historical Castle in Kastamonu (Turkey). Natural Hazards, Vol. 62: 255-274.

Tunusluoğlu, M.C., Zorlu, K., 2009. Rockfall hazard assessment in a cultural and natural heritage (Ortahisar Castle, Cappadocia, Turkey). Environmental Geology, 56(5):963-972.

Turner, A.K., Schuster, R.L., 2012. Rockfall Characterization and Control, Transportation Research Board, National Academy of Sciences, Washington D.C., 658 p.

Varnes, D. J., 1978. Slope movement types and processes, In: R. L. Schuster and R. J. Krizek, Eds., Landslides, Analysis and Control, National Academy of Sciences, pp. 11-33.
Volkwein, A., Schellenberg, K., Labiouse, V., Agliardi, F., Berger, F., Bourrier, F., Dorren, L. K. A., Gerber, W., Jaboyedoff, M.,2011. Rockfall characterization and structural protection-a review. Natural Hazards and Earth System Sciences, 11, 2617-2651.

Wyllie, D.C., 2015. Rock Fall Engineering. CRC Press, Taylor \& Francis Group. 270 pp.

Zorlu, K., Tunusluoglu, M.C., Gorum, T., Nefeslioglu, H.A., Yalcin, A., Turer, D., Gokceoglu, C., 2011. Landform effect on rockfall and hazard mapping in Cappadocia (Turkey). Environmental Earth Sciences. 62, 8, 1685-1693. 